MAREK MARCZEWSKI

LUBLIN

\title{
SPROSTAĆ WEZWANIU DO EWANGELIZACJI
}

Od zakończenia Soboru Watykańskiego II środowiska formujące duszpasterzy, a w konsekwencji samo duszpasterstwo nie może sprostać wezwaniu do ewangelizacji. Coraz bardziej uświadamiamy sobie fakt, że sytuacja obecna „wymaga przejścia z duszpasterstwa jedynie zachowawczego do duszpasterstwa zdecydowanie misyjnego" ${ }^{1}$. W środowiskach wrażliwych duszpastersko sprowadza się to często do uchwycenia intrygująco brzmiących słów, które są interesujące, ale nie przynoszą spodziewanego owocu ${ }^{2}$. Dzieje się tak dlatego, bo hasła, nawet wspaniałe, nie mają zakotwiczenia w eklezjologii, a dokładnie w»przetłumaczonej« na język pewnego ujęcia teologii pastoralnej, pewnego ruchu i pewnego działania eklezjologii Soboru Watykańskiego II w jej elementach centralnych: osoba, wspólnota ludu Bożego, wspólnota apostolska. To, co bp Ryś napisał o»misji permanentnej« i»nawróceniu pastoralnym « wybrzmiało kilkadziesiąt lat temu w nauczaniu i praktyce duszpasterskiej Sługi Bożego ks. Franciszka Blachnickiego (1921-1987)³; związał on wówczas ze sobą dwa wzajemnie ze sobą powiązane i siebie warunkujące pojęcia: ewangelizacja i wspólnota, wspólnota i ewangelizacja. W tekstach, a przede wszystkim w powołanym do życia Ruchu Światło-Życie, uczył i pozwalał przeżyć prawdę, że budowanie Kościoła jako wspólnoty trzeba rozpocząć od ewangelizacji. Sługa Boży stawiał zarzut współczesnej, zbawczej posłudze Kościoła (tak zwanemu duszpasterstwu), że nie dokonano jeszcze „podstawowego przejścia od duszpasterstwa do

1 Aparecida. V [Piąta] Ogólna Konferencja Episkopatów Ameryki Łacińskiej i Karaibów. Dokument końcowy: Jesteśmy uczniami i misjonarzami Jezusa Chrystusa, aby nasze narody miały w Nim życie, Gubin 2014, s. 370. Podczas Mszy św. odprawionej w Rio de Janeiro na zakończenie Światowego Dnia Młodzieży Ojciec Święty Franciszek powiedział: „Nie możemy pozostawać zamknięci w parafii, w naszych wspólnotach [...]. Nie wystarczy po prostu otwarcie drzwi, aby przyjąć, ale trzeba wyjść przez te drzwi, aby szukać i spotykać! [...]. Myślmy zdecydowanie o duszpasterstwie, poczynając od peryferii, poczynając od tych, którzy są najdalej, od tych, którzy zwykle nie przychodzą do parafii. Oni są zaproszonymi VIP-ami. Idźmy i szukajmy ich na skrzyżowaniach ulic" (OsRomPol 10(2013), s. 18). Skróty bibliograficzne, prócz zaznaczonych i wyjaśnionych w tekście, na podstawie: J. Warmiński, Skróty bibliograficzne z zakresu nauk humanistycznych, cz. 1, Lublin 2013.

2 Tak na przykład odbieram tekst bpa Grzegorza Rysia Nawrócenie pastoralne, zamieszczony w pracy zbiorowej Polskie drogi nowej ewangelizacji (red. K. Święs, D. Lipiec, Lublin 2014, s. 11-19).

3 M. Zając, Ks. Franciszek Blachnicki (1921-1987), w: 50 lat teologii pastoralnej na Katolickim Uniwersytecie Lubelskim Jana Pawła II, Lublin 2009, s. 143-156. 
ewangelizacji, a tymczasem jest to zwrot kopernikański, który musi się dokonać w naszej świadomości" ${ }^{\text {. }}$. Wprawdzie dokonało się to w nauce, w teologii, ale nie w praktyce, w zbawczej posłudze Kościoła. Uważał, że stosuje się ten termin nieprawidłowo, opacznie rozumiejąc jego znaczenie, co musi doprowadzić do konfliktu: „próbujemy »czapką soborową" przykryć wszystko to, co było i co jest, ale niczego nie zmieniamy. Pod tą "pokrywką« mieści się to samo, co dawniej, gdy tymczasem koncepcja duszpasterstwa i koncepcja ewangelizacji różnią się zasadniczo tym, że jedna jest statyczna, a druga dynamiczna [...]. Duszpasterstwo jest nastawione na owczarnię, którą się trzeba opiekować, o którą się trzeba troszczyć, której trzeba zapewnić paszę. W całej tej koncepcji z góry jest jakaś determinacja na zachowanie tego, co jest. Nie ma w niej dynamiki zdobywczej, misyjnej, apostolskiej. Tymczasem już w samym słowie »ewangelizacja« jest to »euentes«- »idąc«: »idąc nauczajcie«. Słysząc słowo »ewangelizacja«, widzimy ludzi w ruchu, apostołów, którzy biorą laskę i torbę podróżną i dokądś idą"5. Doświadczenie tej prawdy przez

4 F. Blachnicki, Rekolekcje dla Wspólnoty Kapłanów Chrystusa Sługi, red. G. Wilczyńska, Lublin 1991, s. 11; M. Marczewski, Od duszpasterstwa ku ewangelizacji. Stuga Boży ksiądz Franciszek Blachnicki (1921-1987), w: Sto lat polskiej katechezy, red. R. Czekalski, Kraków 2001, s. 103-118.

5 F. Blachnicki, Rekolekcje dla Wspólnoty Kapłanów Chrystusa Stugi, s. 12. „Terminu »ewangelizacja« użyto po raz pierwszy w 1817 r. w misjologii protestanckiej. Pojęcie to oznaczało wówczas działalność wędrownych protestanckich kaznodziejów oraz popularyzację Biblii w celu pozyskania nowych wyznawców. Z upływem lat termin ten został włączony do teologii katolickiej i był używany w znaczeniu ścisłym - jako pierwsze głoszenie Ewangelii oraz w znaczeniu szerokim - jako działalność apostolska, misyjna, katechetyczno-wtajemniczająca i duszpasterska (por. DCG 49). Ewangelizacja była określana w Kościele jako przepowiadanie o charakterze misyjnym, które ma na uwadze zapoczatkowanie wiary (DCG 17). Takie rozumienie terminu »ewangelizacja« utrwaliło się w polskiej literaturze katechetycznej jako tzw. rozumienie ścisłe. R. Murawski definiuje je następująco: ewangelizacja oznacza pierwsze głoszenie Ewangelii i zmierza do zapoczątkowania wiary. Obok ścisłego znaczenia ewangelizacji, w nauczaniu Kościoła istniał szerszy sposób rozumienia tego pojęcia. Według niego, ewangelizacja jest głoszeniem Chrystusa, dokonywanym zarówno świadectwem życia, jak i słowem (KK 35). Od Soboru Watykańskiego II zauważa się ewolucję rozumienia terminu. Dekret o misyjnej działalności Kościoła wskazuje na ewangelizację jako synonim przepowiadania misyjnego (por. DM 6). Ten sam dokument w dalszej części ukazuje ewangelizację już nie tylko jako głoszenie zbawczego orędzia, ale jako całą działalność misyjną Kościoła (por. DM $23,27)$. W innych dokumentach soborowych ewangelizacja oznacza wszelką posługę słowa Bożego (KK 35; DB 6; KDK 44; DA 2). Paweł VI w adhortacji apostolskiej Evangelii nuntiandi przedstawia ewangelizację w najszerszym zakresie, utożsamiając ją z działalnością Kościoła (por. EN 18). W nauczaniu Jana Pawła II jest widoczne podobne przechodzenie od ścisłego do coraz szerszego znaczenia ewangelizacji [...]. W znaczeniu ścisłym jest to, według niego, przepowiadanie Ewangelii tym, którzy jej jeszcze nie słyszeli, albo też przyjęli ją w taki sposób, który nie wywołał nawrócenia (por. RM 33-34). Ewangelizacja jest wówczas działalnością misyjną ad gentes, w której Kościół wychodzi ku ludziom trwajacym w mroku śmierci. Pierwsze głoszenie Ewangelii dotyczy nie tylko pogan czy niewierzących, ale również wszystkich chrześcijan, którym brakuje podstawowego doświadczenia inicjacji chrześcijańskiej [...]. W znaczeniu szerokim ewangelizacja jest to działalność apostolska Kościoła (por. TMA 25; EV 78). Nie można jej traktować jako jednej z wielu czynności Kościoła, ponieważ wypływa ona z jego natury i powołania. Kościół istnieje bowiem dla ewangelizacji (EN 
Sługę Bożego i wyciągnięcie z niej podstawowej konsekwencji, a mianowicie, że Kościół winien stawać się ewangelizującym: „Kościół jest dla ewangelizacji” (EN 14), doprowadziło go nawet do pomysłu zastąpienia nazwy »teologia pastoralna« »teologią ewangelizacji«. Twierdził bowiem, że „teologia pastoralna obejmuje tylko jeden wycinek ewangelizacji, gdy pojęcie ewangelizacji jest o wiele szersze, bo obejmuje wszystkie tereny do zdobycia [...]. W ramach tej szerokiej wizji będzie potem miejsce na »Seelsorge« [duszpasterstwo], na troskę o dusze, które już uwierzyły i trzeba im zapewnić systematyczną opiekę, pomoc" ${ }^{\text {" }}$. Uważał także, że w świetle adhortacji apostolskiej papieża Pawła VI Evangelii nuntiandi na nowo trzeba przemyśleć zagadnienie misji oraz katechezy. Jeśli chodzi o sprawę pierwszą, to sugerował, by tradycyjne misje ludowe, które „już się przeżywają”, stawały się rekolekcjami ewangelizacyjnymi. Natomiast w katechezie należy wyzwolić te możliwości, które prowadziłyby do wychowywania świadków, gdyż „ten tylko może zachować wiarę dla siebie, kto potrafi przekazywać ją innym, bo zachowanie dokonuje się w przekazywaniu. Rządzi tu to samo prawo, co w miłości, że przyjmowanie dokonuje się w dawaniu"”.

Zastanawiając się nad »źródłem « niewystarczalności dotychczasowego duszpasterstwa, wskazał na utracenie przez Kościół środowiska wychowawczego: „Dawniej zadanie wychowania nowych chrześcijan spełniało w głównej mierze środowisko społeczne, przeniknięte w swych prawach, urządzeniach, instytucjach i zwyczajach atmosferą chrześcijańską. Rodzina wraz z środowiskiem społecznym stanowiła pewnego rodzaju społeczny katechumenat. W tych warunkach - pisał - duszpasterstwo, ograniczające się do stwarzania obiektywnego i ontologicznego fundamentu dla wychowania chrześcijańskiego, przez głoszenie Słowa Bożego i sprawowanie sakramentów świętych, oraz do stwarzania kultowych ram służby Bożej, mogło uchodzić za wystarczające. Dzisiaj natomiast coraz bardziej odczuwa się, że tego rodzaju minimalistyczne duszpasterstwo, nie wspierane pracą i oddziaływaniem środowiska wychowującego, zawisło jakby w próżni i nie jest zdolne samo osiągnąć celu, jakim jest wychowanie chrześcijan żyjących wiarą i kształtujących swoje życie

14) [...]. Ewangelizacja w ujęciu Jana Pawła II nie jest zjawiskiem statycznym, jednorazowym, lecz dynamicznym i złożonym, które trwa i rozwija się w czasie, aż do powtórnego przyjścia Chrystusa. Ewangelizacja rozumiana jako działalność apostolska Kościoła jest procesem, tworzonym przez: pierwsze głoszenie Chrystusa (por. RM 44-45), ewangeliczne świadectwo życia (por. RM 42), nawrócenie i Chrzest Święty (por. RM 46-47), formowanie Kościołów lokalnych (por. RM 48-50), działalność ewangelizacyjną wspólnot podstawowych (por. RM 51), inkulturację Ewangelii (por. RM 52-54) oraz dialog w braćmi o innych przekonaniach religijnych (por. RM 58-59)" (P. Skiba, Katecheza ewangelizacyjna w nowych ruchach i wspólnotach kościelnych. Studium katechetyczne wybranych ruchów wspólnot kościelnych, Lublin 2006, s. 34-36). Zob. M. Marczewski, Ewangelizacja - nawrócenie - inicjacja - służba, w: Katecheza ewangelizacyjna. Poszukiwania koncepcji, red. P. Mąkosa, Lublin 2010, s. 145-162.

6 Tamże s. 13-14.

7 Tamże. 
z wiary. Środowisko społeczne bowiem uległo już pawie całkowicie laicyzacji, a laicyzacja ta wraz z towarzyszącym mu rozkładem moralnym, dzięki zwłaszcza takim technikom propagandowym jak prasa, radio i telewizja coraz bardziej wdziera się poza próg życia rodzinnego"

W tej sytuacji, gdy nie wystarcza już »duszpasterstwo dnia wczorajszego «(Pius XI), należy wypracować jego nowe ujęcie, które Sługa Boży określił jako »duszpasterstwo typu wychowawczego«, to znaczy taką formułę zbawczej posługi Kościoła, która „nie ogranicza się do rzucania ziarna, ale troszczy się zarówno o przygotowanie gleby, która ma ziarno przyjąć, jak i o dalszy wzrost tego ziarna, śledząc go i wspomagając krok za krokiem. Duszpasterstwo w typie rolnika-siewcy trzeba dziś coraz bardziej uzupełniać duszpasterstwem w typie pracy ogrodnika. Ten typ pracy duszpasterskiej z natury swej jest pracą o charakterze elitarnym. W tym sensie można powiedzieć, ze z duszpasterstwa masowego coraz bardziej przechodzimy dziś do duszpasterstwa elitarnego, poświęcającego główną troskę wychowaniu małych grup elitarnych" .

Ksiądz Blachnicki był daleki porzuceniu tak zwanego duszpasterstwa masowego, którego modelem jest »Kościół ludowy « ${ }^{10}$, na korzyść »Kościoła elit«. Kierowała nim troska o zachowanie lub odzyskanie mas dla Kościoła, o rechrystianizację środowiska przy pomocy odpowiednio przygotowanych, a więc odpowiedzialnych wiernych świeckich ${ }^{11}$. To jednak pociąga za sobą i wymaga myślenia w zupełnie innych kategoriach o Kościele. Nie jako o»rzeczy«, »przedmiocie«, ale jako o»osobie«, "podmiocie«. Pytanie bł. Pawła VI: Kościele, co mówisz o samym sobie? było skierowane nie tylko do Ojców Soboru Watykańskiego, ale do »całego « Kościoła, „było - jak pisał św. Jan Paweł II - zarazem otwarte ku wszystkim, którzy ten

8 F. Blachnicki, Metoda przeżyciowo-wychowawca dziecięcych rekolekcji zamkniętych. (Studium pedagogiczno-pastoralne), Lublin 1963 (ArKUL), s. I.

9 Tamże, s. I-II.

10 Podstawowe pojęcia socjologii religii w eksplikacji ks. Janusza Mariańskiego, oprac. i wyboru dokonał M. Marczewski, Lublin 2013, s. 195-196.

11 „Kościół powstał po to, aby poprzez rozszerzanie królestwa Chrystusa po całej ziemi ku chwale Boga Ojca uczynić wszystkich ludzi uczestnikami zbawczego odkupienia i by przez nich cały świat rzeczywiście został skierowany ku Chrystusowi. Każda bowiem działalność Mistycznego Ciała, zwrócona ku temu celowi, nazywa się apostolstwem, które Kościół wypełnia przez wszystkie swoje członki, jednakże różnymi sposobami. Powołanie chrześcijańskie ze swej natury jest bowiem również powołaniem do apostolstwa [...]. Ludzie świeccy, mający uczestnictwo w funkcji kapłańskiej, prorockiej i królewskiej Chrystusa, wypełniają natomiast swe zadania w posłannictwie całego ludu w Kościele i w świecie. Rzeczywiście prowadza oni apostolstwo przez działalność skierowanq ku ewangelizacji i uświęcaniu ludzi oraz ku przenikaniu i ksztattowaniu porządku rzeczy doczesnych zgodnie $z$ duchem ewangelicznym, tak by ich działanie w tym porządku stanowiło w sposób widoczny świadectwo o Chrystusie i stużyło do zbawienia ludzi" (DA 2; podkr. moje: M. M.). 
podmiot tworzą"12. Nowa eklezjologia pociąga za sobą z kolei nowe ujęcie i rozumienie zasady życia Kościoła, a zarazem teologii pastoralnej jako teologii tego życia ${ }^{13}$.

Wstępne refleksje pozwoliły na zakreślenie trzech tematów, którymi warto się zająć: (1) stanem polskiej religijności, (2) konsekwencjami pastoralnymi wynikającymi z wypracowanej przez Ojców Soboru »eklezjologii communio«, (3) »przetłumaczoną« na język pewnego ruchu, pewnego działania, eklezjologii Soboru w jej elementach centralnych: osoby, wspólnoty ludu Bożego, wspólnoty apostolskiej. Każdy z nich może stanowić przedmiot osobnego studium lub kilku książek. W tym opracowaniu zakreślimy jedynie linie refleksji.

\section{Religijność i moralność doby (post)modernizmu}

Już w pierwszych zdaniach zwróciliśmy uwagę na charakterystyczną dla Księdza Blachnickiego niezwykłą wrażliwość na analizy socjologii religii, która „bada wzajemne związki i oddziaływania religii i społeczeństwa”, a także „uwarunkowania społeczne kultury religijnej, komunikowania i działania religijnego, kształtowanie się ról społecznych i typów działań w społeczeństwie, wreszcie skutki instytucjonalizacji i dezinstytucjonalizacji społecznej w życiu religijnym. Socjologia nie pomija wpływów religii na życie społeczne [...], na różne grupy w łonie całościowego społeczeństwa i na jednostki" ${ }^{14}$. Jego krytyka polskiego typu religijności związana była z pytaniem o skuteczność katechezy w Polsce. Pisał, że w naszym kraju żyjemy złudzeniami o jej skuteczności: „W ten sposób można było »uczyć religii« w czasach, kiedy katecheta miał do czynienia $\mathrm{z}$ dziećmi pochodzącymi z rodzin wierzących i ze środowiska społecznego przenikniętego atmosferą religijną, z dziećmi, u któ-

\footnotetext{
12 „Podmiot »Kościół« jest bowiem jedyną w swoim rodzaju wspólnotą. Jest to niewątpliwie wspólnota wiary, wspólnota odpowiedzi dawanej Bogu na Jego Słowo, wspólnota ludzi, których łączy i zespala ta odpowiedź. Wspólnota wyrastająca z tej odpowiedzi, z dialogu z Bogiem określa jakby pionowy wymiar Kościoła. Równocześnie zaś wspólnota ta jest otwarta ku wszystkim ludziom. Wiara zespolona dialogiem kształtuje wymiar poziomy Kościoła. Nie jest to jedynie wymiar »humanistyczny«. Wymiar poziomy wynika z pionowego, odpowiada on zakresowi Objawienia, o którym wiemy, że »Bóg chce, aby wszyscy ludzie byli zbawienia i doszli do poznania prawdy« $(1 \operatorname{Tm} 2,4)$. Świadomość Kościoła nie może być ciaśniejsza. Musi odpowiadać uniwersalizmowi Bożego planu zbawienia i dzieła odkupienia" (K. Wojtyła, U podstaw odnowy. Studium o realizacji Vaticanum II, wyd. 2, Kraków 1988, s. 33-34).

13 Nawiązuję tu do tytułu pracy F. Klostermanna poświęconej teologii Kościoła jako wspólnoty: Prinzip Gemeinde. Gemeinde als Prinzip des kirchlichen Lebens und der Pastoraltheologie als der Theologie dieses Lebens (Wien 1965).

14 J. Mariański, Rola i znaczenie socjologii religii w refleksji pastoralnej ks. Franciszka Blachnickiego, w: Ks. Franciszek Blachnicki - katechetyk i pastoralista. Wdwudziestą rocznicęśmierci Sługi Bożego, red. R. Buchta, Katowice 2009, s. 37-38. „Ks. Blachnicki zalicza socjologię religii do głównych i nieodzownych nauk pomocniczych teologii pastoralnej, którą definiuje jako naukę o urzeczywistnianiu się Kościoła we wspólnocie” (tamże, s. 40).
} 
rych nie było problemu wiary. Były one wierzące nie dzięki, ale mimo katechizacji, polegającej na wkuwaniu na pamięć formuł katechizmowych"15.

Dzisiaj jesteśmy świadkami przeobrażeń społeczno-kulturowych, które oddziaływają także na sferę religii i moralności. Przed wieloma z nich ostrzegał i wskazywał na ich obecność. Wskazuje się na następujące procesy, jakie zachodzą pomiędzy społeczeństwem (osobami) i religią: indywidualizację ${ }^{16}$, pluralizm $^{17}$, globalizację ${ }^{18}$, sekularyzację $^{19}$, odkościelnienie ${ }^{20}$, nową duchowość ${ }^{21}$, a także tworzy scenariusze przemian religijności ${ }^{22}$. Ze swej strony pragniemy skierować uwagę na coraz bardziej charakterystyczną dla współczesnego społeczeństwa polskiego selektywną i pozakościelną religijność i moralność. Jedno i drugie są ze sobą związane: nie ma bowiem religijności bez moralności, a moralność jest integralnym elementem religijności ${ }^{23}$.

Procesy sekularyzacji i pluralizacji społeczno-kulturowej sprawiają, że „religia i moralność tworzą coraz częściej odrębne systemy regulacji ludzkich zachowań”, a religijne interpretacje życia ustępują świeckim (sekularyzm): „jedne interpretacje religijne są zastępowane innymi, komunikowanie moralne zmienia się w komunikowanie na temat moralności, postępowanie - w dyskurs etyczny"24. Charakterystyczną cechą społeczeństw (przed)nowoczesnych była dość ścisła relacja pomiędzy kodeksem moralnym, przynależnością grupową i religią. To religii przypadała "misja " przedstawiania podstawowych wartości, wokół której budowano system wartości: „To stanowisko, choć niegdyś nader rozpowszechnione, staje się coraz rzadsze i nie można nawet powiedzieć, aby było charakterystyczne dla większości katolików praktykujących" ${ }^{25}$. W warunkach modernizacji społecznej, jak podkreśla ks. Janusz Mariański, „następuje stopniowe oddzielenie sfery sakralnej

15 F. Blachnicki, Katechetyka fundamentalna, Warszawa 2006, s. 106.

16 Podstawowe pojęcia socjologii religii w eksplikacji ks. Janusza Mariańskiego, s. 49-62.

17 Tamże, s. 95-109.

18 Tamże, s. 33-48.

19 Tamże, s. 131-144.

20 Tamże, s. 85-93.

21 Tamże, s. 21-31.

22 Tamże, s. 145-156.

23 J. Mariański, Religia i moralność w przednowoczesnych i nowoczesnych społeczeństwach, w: O społeczeństwie, moralności i nauce. Miscellanea, red. W. Pawlik, E. Zakrzewska-Mentrys, Warszawa 2008, s. 211-229.

24 Tamże, s. 212.

25 J. Maître, Religia a przemiany społeczne. W: Socjologia religii. Wprowadzenie, red. F. Houtart, Kraków 1962, s. 54. Warto zwrócić uwagę na to stanowisko odnoszące się wprawdzie do Francji, ale przecież już w tym czasie bardzo poważnie odbierane między innymi przez Księdza Blachnickiego jako ostrzeżenie dla katolicyzmu polskiego, po badaniach ks. Władysława Piwowarskiego na Warmii. Nieco później pojawiają się badania ks. Janusza Mariańskiego: Moralność w procesie przemian. Szkice socjologiczne (Warszawa 1990), by już na dziesięciolecia pozostać trwałym ostrzeżeniem i świadectwem dokonujących się zmian na polu religijno-moralnym katolików polskich. 
od świeckiej, religijności od moralności. Moralność, która była w społeczeństwach istotnym elementem więzi społecznej, traci powoli swoje funkcje koordynacyjno-regulacyjne działań”26. Poszczególne dziedziny życia społeczno-kulturowego uniezależniają się od wpływu religii. Życie zaczyna dzielić się na szereg samoistnie bytujących fragmentów, człowiek współczesny chce suwerennie decydować o dobru i złu moralnym, choć w postmodernistycznej ambiwalencji nie jest on w stanie precyzyjnie rozróżnić pomiędzy tym, co jest dobre, a co złe: „Tak zwany ponowoczesny człowiek nie podejmuje decyzji moralnych na podstawie jednoznacznych kryteriów dobra lub zła, uświęconych autorytetem tradycji religijnej, lecz kieruje się opcjami aksjologicznymi opartymi na kryteriach zindywidualizowanych. Tracą na znaczeniu normy oparte nie tylko na autorytecie religijnym, ale i na autorytecie społeczno-kulturowym"27, a moralność ewoluuje w kierunku autonomicznego sumienia: „Sakralizuje się własne »ja« jako źródło moralności ${ }^{28}$.

W jednej z ostatnich książek Lubelskiego socjologa czytamy, że daje o sobie znać zmiana w religijności, bardziej wyraźna w dwóch środowiskach społecznych, a mianowicie wśród młodzieży i młodych kobiet, która może zapowiadać dalszą ewolucję religijności, szczególnie w zakresie desakralizacji życia małżeńskiego i rodzinnego (»pełzająca i przyspieszona sekularyzacja«). Granicą owej transformacji czy "procesu przemian«, jak sugeruje tytuł książki, ma być rok 2005: „Przez całe lata dziewięćdziesiąte utrzymywał się wysoki poziom religijności społeczeństwa polskiego, choć widoczne były zaczątki procesów charakterystycznych dla modernizacji [...]. Dopiero po 2005 roku przemiany w religijności nabierają pewnego przyspieszenia, kończy się okres opóźnionej (odłożonej) sekularyzacji”29. Nie miejsce tu na szczegółowe analizy, ale warto sięgnąć do przywołanej książki dotyczącej stanu praktyk religijnych w Polsce, a to dlatego, że stanowią dobry wskaźnik dla określenia chrześcijańskiej religijności: „Spadek udziału w praktykach religijnych, zwłaszcza niedzielnych, pociąga za sobą negatywne zmiany w sferze przekonań

\footnotetext{
26 Mariański, Religia i moralność w przednowoczesnych i nowoczesnych społeczeństwach, s. 219-220.

27 Tamże, s. 221 (podkr. moje: M. M.).

28 Tamże, s. 228.

29 J. Mariański, Praktyki religijne Polsce w procesie przemian. Studium socjologiczne, Sandomierz 2014, s. 10. Wyróżnia się dwa etapy w analizie przemian religii jako wartości po roku 1989 (tak zwanej transformacji): etap pierwszy, do roku 2005, który charakteryzuje się wysokimi deklaracjami wiary i praktyk religijnych, a także odgrywaniem znaczącej roli religii w życiu jednostek i rodziny, jako wartości »uznawanej« i»realizowanej«, oraz etap drugi, po śmierci Ojca Świętego św. Jana Pawła II, w którym „utrzymywały się jeszcze na tym samym poziomie deklaracje wiary, ale zmalała intensywność praktyk religijnych w niektórych kategoriach społecznych [...]. Religia stawała się wartością uznawaną, ale tylko częściowo realizowaną. W miarę nasilania się wpływów globalizacji, otwarcia na Zachód i oddziaływania mediów, wzrastała permisywność społeczeństwa, zwłaszcza młodego pokolenia. Indywidualizm i pluralizm poglądów odgrywają coraz większą rolę w życiu codziennym Polaków" (U. Swadźba, Wartości - pracy, rodziny i religii - ciągłość i zmiana. Socjologiczne studium społeczności śląskich, Katowice 2012 - cyt. za: Mariański, Praktyki religijne Polsce w procesie przemian. Studium socjologiczne, s. 11).
} 
religijnych. Zmniejszanie się zaangażowania $\mathrm{w}$ realizację praktyk religijnych oddziałuje na różne systemy normatywne. $Z$ badań socjologicznych wynika, że wraz ze spadkiem religijności kościelnej (głównie praktyk religijnych) zanika moralny konsens w społeczeństwie, a także społecznie zobowiązująca etyka"30.

Analizując wyniki dotyczące praktyk religijnych ze względu na strukturę wieku Ksiądz Mariański wskazuje na "daleko idącą "przepaść " pokoleniową" ${ }^{1}$. Wśród dorosłych Polaków od 37, 0\% do 51, 7\% praktykuje systematycznie, a od 70, 9\% do $85,2 \%$ niesystematycznie. Jeśli chodzi o młodzież, to od $29,8 \%$ do $39,0 \%$ określała siebie jako systematycznie praktykująca, a od $55,9 \%$ do $71,5 \%$ jako niesystematycznie. W pierwszej dekadzie XXI wieku nastąpiło lekkie przyspieszenie spadku zaangażowania w praktyki religijne katolików polskich. W roku 2012 w porównaniu z 1991 rokiem spadek ten wyniósł 9, 9\%. W tym samym czasie wskaźnik niepraktykujących zwiększył się o $6,2 \%^{32}$.

Według sondażu CBOS w kwietniu 2014 roku udział we mszy niedzielnej, nabożeństwach lub spotkaniach religijnych deklarowało 6,1\% dorosłych kilka razy w tygodniu; 45, 6\% - raz w tygodniu; $14,5 \%$ - jeden lub dwa razy w miesiącu; 20,8\% - kilka razy w roku; 13,4\% - nie uczestniczy w ogóle ${ }^{33}$. Młodzież w badaniach przeprowadzonych przez ten sam ośrodek opinii w $7,0 \%$ deklarowała uczestnictwo kilka razy w tygodniu; 38, $0 \%$ - raz w tygodniu; $15,0 \%$ - przeciętnie jeden lub dwa razy w miesiącu; 20, 0\% - kilka razy w roku; 20, 0\% - w ogóle nie uczestniczy: Czynnikiem wyraźnie różnicującym deklaracje młodzieży dotyczące udziału w praktykach religijnych jest miejsce zamieszkania. Uczniowie z obszarów wiejskich w ponad połowie uczestniczą regularnie w praktykach religijnych (54\%), z miast poniżej 20 tys. mieszkańców - 39\%, z miast od 20 do 100 tys. mieszkańców - 36\%, z miast od 101 tys. do 500 tys. mieszkańców - 32\% i z miast powyżej 501 tys. mieszkańców - 21\%"34. Przedstawione powyżej wskaźniki praktykujących uprawniły Księdza Mariańskiego do stwierdzenia, że „spadek uczestnictwa w praktykach niedzielnych w Polsce będzie odbywał się w sposób mniej spektakularny niż w krajach zachodnich. Nie bez znaczenia jest fakt, że religijna tożsamość osobowa wielu młodych ludzi powoli przekształca się z»wrodzonej« w»zdobytą« lub "konstruowaną" $"$ ".

Z porównania danych dotyczących coniedzielnego uczestniczenia we Mszy św. (dominicantes) i praktykujących spowiedź i komunię św. wielkanocną (paschantes) wynika, że „wskaźnik "paschantes« kształtuje się w Polsce na poziomie od $70 \%$ do $80 \%$ w odniesieniu do dorosłych katolików i na nieco niższym poziomie

\footnotetext{
30 Tamże, s. 42. Omówienie tej publikacji: KwPD 14(2015), s. 303-314.

31 Mariański, Praktyki religijne Polsce $w$ procesie przemian, s. 66.

32 Tamże, s. 63-64.

33 Tamże, s. 80.

34 Tamże, s. 91.

35 Tamże, s. 98.
} 
w środowiskach młodzieży szkolnej (od 60\% do 70\%). Według informacji wielu duszpasterzy powoli i w naszym kraju rozpoczyna się kryzys sakramentu pokuty. Prawdopodobnie rzeczywiste wskaźniki respektowania obowiązku spowiedzi w okresie wielkanocnym są znacznie niższe i nie przekraczają $60 \%$ ogółu zobowiązanych"36.

Praktyki nadobowiązkowe, zwane niekiedy »pobożnymi«lub »intensywnymi«, takie jak: częsta komunia św., modlitwa indywidualna i rodzinna, zamawianie intencji mszalnych, zwyczajowe praktyki religijne w rodzinie, pielgrzymki i rekolekcje, „pełnią ważne funkcje integracyjne w społeczeństwie i w kształtowaniu tożsamości osobowej [...] symbolizują związek z»sacrum« oraz przynależność katolików do wspólnoty Kościoła”. Część z nich zanika lub podlega prywatyzacji, część „utrzymuje się na niezmienionym poziomie, wreszcie część zyskuje na znaczeniu [...]. Szczególnie uprzywilejowanym miejscem realizacji zwyczajów religijnych był i jest dom rodzinny" 37 .

Godnym odnotowania jest fakt wzrostu częstej komunii św.: od 7, 8\% w 1980 roku do 16, 1\% w 2012 roku, a więc o dziewięć punktów procentowych. Nieco więcej niż połowa badanych polskich katolików modli się codziennie lub prawie codziennie, około czwarta część przynajmniej raz w miesiącu, a co piąta - nie modli się. Ci, którzy się modlą w miarę regularnie, czynią to najczęściej wieczorem, rzadziej rano. Zdaniem ks. Mariańskiego „zmiany w praktykach codziennej modlitwy w życiu katolików są dość wyraźne, idące w kierunku odchodzenia od tego typu praktyk religijnych"38. W latach 1991-2012 wśród osób w wieku 18-24 lata nastąpił spadek o 18, 0\%, a wśród osób w wieku 25-34 lat o 10, 2\% (s. 139). Mówi się o przejściu od regularnej do okolicznościowej modlitwy, a „wskaźniki regularnej modlitwy codziennej odnoszą się co najwyżej około 40\% badanych Polaków"39.

Rodzinne rytuały, obrzędy i zwyczaje religijne - jak wykazują sondaże opinii publicznej - utrzymują się wciąż na wysokim poziomie: „W sondażu CBOS z marca 2012 roku dorośli Polacy deklarowali w następujący sposób przestrzeganie praktyk i zwyczajów religijnych w ich rodzinach: post w Środę Popielcową - 89, $0 \%$ badanych, posypywanie głowy popiołem w Środę Popielcową - 74, 8\%, udział w rekolekcjach wielkopostnych - 70, 3\%, udział w nabożeństwie Drogi krzyżowej i Gorzkich Żali - 59, 5\%, poświęcenie palemki w Niedzielę Palmową - 84, 9\%, udział w kościelnych obchodach Triduum Paschalnego - 67, 8\%, zachowanie postu w Wielki Piątek lub Sobotę - 79, 3\%, poświęcenie pokarmu w Wielką Sobotę (tzw. święcone) - 93,0\%, udział w rezurekcji (porannej Mszy w Wielką Niedzielę) - 69, $1 \%$, dzielenie się z najbliższymi święconym jajkiem - 92, 7\%"40.

\footnotetext{
36 Tamże, s. 117

37 Tamże, s. 125-126.

38 Tamże, s. 128, 138

39 Tamże, s. 146.

40 Tamże, s. 167.
} 
Dane te mogą mylić. Dlatego godne uwagi jest przekonanie socjologów, że „uczestnictwo w niektórych rytuałach nie wymaga nawet zdecydowanej wiary, odbywa się z pobudek pozareligijnych. Dla znacznej części Polaków uczestnictwo w obrzędach kościelnych jest wartością niemal autonomiczną, a spełniany rytuał nie wymaga zdecydowanej i osobowo przeżywanej wiary [...]. Odejście od religii jako systemu wierzeń nie oznacza zerwania z obrzędową i tradycyjna formą świąt kościelnych"41.

Dokonana analiza religijności Polaków, z konieczności znacznie okrojona, pozwala na dokonanie wnikliwej refleksji nad stanem życia religijnego Polaków. Analiza praktyk nie wyczerpuje całości zagadnienia. Dlatego należy uwagę skierować na zaznaczający się dysonans pomiędzy realizowaną sferą powinności kultowych a zaniedbywaną, niekiedy wprost kontestowaną przez wierzących sferą powinności moralnych, a więc coraz bardziej wyraźny problem »moralności pozakościelnej«i isselektywnej « ${ }^{42}$.

\section{2. »Eklezjologia communio«}

W przekonaniu Maxa Secklera, profesora teologii fundamentalnej w Tybindze, charakterystyczny dla eklezjologii Vaticanum II „motyw »communio« należy w swej nowotestamentalnej pełni znaczenia - do najbardziej centralnych idei chrześcijaństwa. Jest istotny tak dla rozumienia samego misterium zbawienia, jak i jego urzeczywistniania. Idea komunii zawiera w sobie wiele wymiarów: odnosi się do trynitarnej istoty Boga i relacji ludzi do Boga, a także do kształtowania relacji międzyludzkich: dotyka osobowych wymiarów głębi doświadczenia religijnego i sięga także ku instytucjonalnym strukturom społeczeństwa oraz ich prawnemu uporządkowaniu. Jako przewodnia idea teologiczna, a jednocześnie antropologiczna, socjologiczna i eklezjologiczna, zawiera w sobie potencjał reformatorski i wywrotowy [...]. W recepcji nauczania tego soboru myśl o komunii stała się właściwie punktem konstrukcyjnym odnowionego obrazu Kościoła”" ${ }^{43}$.

\footnotetext{
41 Tamże, s. 163, 178.

${ }_{42}$ Został przedstawiony w następujących pracach Księdza Mariańskiego: Kontrowersje wokół relacji religii i moralności. Tożsamość czy rozbieżność? Studium socjologiczne (Toruń 2014) oraz Wiara i wierzenia Polaków w niestabilnej nowoczesności. Studium socjologiczne (Lublin 2014).

${ }_{43}$ M. Seckler, Die Communio-Ekklesiologie, die theologische Methode und die Loci-theologici-Lehre Melchior Canos, w: In Eo qui confortat, red. A. Proniewski, A. M. Jakoniuk, A. Dębski, Białystok 2009, s. 209 - za: M. Jagodziński, Recepcja soborowego paradygmatu »communio« w teologii systematycznej, w: Studia soborowe [t. 2. cz. 1]: Historia i recepcja Vaticanum II, red. Michała Białkowski, Toruń 2014, s. 661-662.
} 
Ksiądz Profesor Marek Jagodziński przywołując tę opinię stwierdza, że podstawowym zadaniem Kościoła epoki Soboru Watykańskiego II było nawiązywanie pełniejszej komunikacji wewnątrz wspólnoty eklezjalnej i ze współczesnym światem. Przypisuje mu się również autorstwo zwrotu od informacji ku komunikacji, a używanie pojęcia »communio« na oznaczenie wspólnoty eklezjalno-trynitarnej zakłada istnienie komplementarnego pojęcia »communicatio«. Wielu autorów uważa, że podstawowym modelem wewnętrznej struktury dokumentów soborowych jest triada communio - communicatio - participatio" ${ }^{44}$. We współczesnej teologii pastoralnej ${ }^{45}$, w jej nurcie eklezjologicznym ${ }^{46}$, „eklezjologia communio « stała się podstawą wypracowania zasady teologii pastoralnej i opartego na nim lub wyprowadzonej z niej zbawczej posługi Kościoła. Ujęcie Kościoła jako wspólnoty, a w konsekwencji wskazanie na Kościół-Wspólnotę jako zasadę teologii pastoralnej i duszpasterstwa, stanowi - na obecnym etapie myśli pastoralnoteologicznej - końcowy etap eklezjologicznej dedukcji tej dyscypliny wiedzy. Jej autorem jest Sługa Boży ks. Franciszek Blachnicki.

U jej podstaw, ujmując zagadnienie rozwoju teologii pastoralnej od strony historycznej, musiało zaistnieć zakorzenienie eklezjologiczne, aby ta dyscyplina teologiczna mogła się w ogóle rozwijać. Za wybitnymi teologami tego czasu, Franciszkiem Ksawerym Arnoldem (1898-1969) i Heinzem Schusterem (1930-1986) Ksiądz Blachnicki stwierdził, że u podstaw rozwoju teologii pastoralnej zaciążył fatalnie nieeklezjologiczny punkt wyjścia i dlatego znalazła się ona w prawdziwym błędnym kole, stawiając u swoich podstaw pojęcie "pasterza« i»duszpasterstwa« jako swoją zasadę formalną. Zamiast bowiem pytać się w świetle istoty Kościoła, jaka jest istota "pasterza« i»duszpasterstwa«, próbowała ona z powyższych pojęć wydedukować określenie istotnych rysów działalności Kościoła, a nawet i samego Kościoła $^{47}$.

\footnotetext{
44 Jagodziński, jw., s. 662-663. W moim przekonaniu rozumienie pojęcia communio przez Księdza Profesora jest swoiste i wydaje się, że "zatraca się« w meandrach komunikacji.

45 F. Blachnicki, M. Marczewski, Wprowadzenie do współczesnej teologii pastoralnej. Od pastoralnoteologicznego aprioryzmu do Kościoła - sakramentu wspólnoty, Kraków 2014.

46 „Przedstawiciele koncepcji eklezjologicznej uważają, że teologii pastoralnej nie można wydedukować ani z pojęcia pastor, jak tego żąda na przykład M. Benger, ani też z istoty teologii jako takiej, czego domaga się R. Füglister. Ich zdaniem jedyną drogą dotarcia do właściwego przedmiotu teologii pastoralnej jest oparcie się na istocie Kościoła" (W. Piwowarski, Eklezjologiczna koncepcja teologii pastoralnej, w: F. Blachnicki, Teologia pastoralna ogólna, t. 1, cz. 1: Wstęp do teologii pastoralnej. Teologiczne zasady duszpasterstwa, Warszawa 2013, s. 114; skrót: TPO I).

47 F. Blachnicki, Idea Kościoła we wspótczesnej literaturze teologiczno-pastoralnej, SSHT 4(1971), s. 40 (podkr. moje: M. M.). Koncepcję teologii pastoralnej doprowadza prawie do absurdu Michael Benger CSsR (1822-1870). Na pytanie, co to jest teologia pastoralna, daje odpowiedź, która a priori zawarta jest już w pytaniu: że jest to nauka o pasterzu, o jego obowiązkach i czynnościach. Na pytanie: kto to jest pasterz, jaka jest jego istota i jakie są jego zadania, odpowiedź znowu jest apriorystyczna - jest powtórzeniem treści zawartej w pytaniu. Sytuacji nie ratuje poprowadzenie linii od kapłana-duszpasterza do Chrystusa, którego kapłan jest zastępcą i kontynuatorem. Na pytanie
} 
Tym, który wyrwał teologię pastoralną z błędnego koła, był przywołany już wcześniej ks. Franciszek Ksawery Arnold. W literaturze teologicznopastoralnej nurt eklezjologiczny teologii pastoralnej wzbogacił ją o próbę zakotwiczenia $\mathrm{w}$ dogmacie chrystologicznym ${ }^{48}$, a konkretnie w nauce o Chrystusie Bogu-Człowieku $^{49}$, która w jego przekonaniu, jako głęboko zakorzeniona w chrześcijaństwie, powinna stać się prototypem kościelnego pośrednictwa. $Z$ tej też racji Arnold znany jest $\mathrm{w}$ teologii pastoralnej jako twórca bosko-ludzkiej zasady teologii pastoralnej i duszpasterstwa. Konstruktywną krytykę tego ujęcia przedstawił Ksiądz Blachnicki w tezie doktorskiej ${ }^{50}$. Ona stała się podstawą wypracowania, na kanwie prac Arnolda, czterech koncepcji (ujęć), zasad duszpasterstwa: (a) »chrystologicznej«, a następnie (b) »personalistycznej«, (c) »personalistyczno-dialogicznej«, (d) "personalistyczno-chrystologicznej «"

a. Pod pojęciem »zasady chrystologicznej« należy rozumieć próbę zakorzenienia wypracowanej przez Księdza Profesora Arnolda »zasady bosko-ludzkiej« w chrystologii, a tym samym ukazania relacji pośrednictwa Kościoła do pośrednictwa Chrystusa. Z chrystologicznej zasady tybińskiego Pastoralisty wyprowadza Ksiądz Blachnicki następujące ustalenia: - Chrystus jest prototypem kościelnego pośrednictwa zbawienia, bo jedność i współdziałanie obu natur w Nim zjednoczonych zakorzenia bosko-ludzką zasadę duszpasterstwa w aspekcie personalistycznym

bowiem, kim był Chrystus, jaka była istota Jego działalności, przychodzi odpowiedź: Chrystus był właśnie Pasterzem. W ten sposób zamyka się ów circulus vitiosus tradycyjnej koncepcji teologii pastoralnej. Zamiast pytać w świetle istoty dzieła zbawczego i Kościoła, jaka jest natura duszpasterza i jakie są jego obowiązki, usiłuje ona z pojęcia pasterza wyprowadzić naturę dzieła zbawczego Kościoła i jego pośrednictwa zbawczego. Benger jest najbardziej typowym przykładem dla całego następnego okresu rozwoju teologii pastoralnej, aż do naszych czasów (TPO I, s. 100-102).

48 F. Blachnicki, Teologia pastoralna ogólna, Cz. 2: Eklezjologiczna dedukcja teologii pastoralnej, Lublin 1971 (skrót: TPO II), s. 53-56; tenże, Idea Kościoła we współczesnej literaturze teologiczno-pastoralnej, s. 66.

49 K. Delahaye, Überlegungen zur Neuorientierung der Pastoraltheologie heute, GiW II, s. 210-211.

50 F. Blachnicki, Pośrednictwo zbawcze Kościoła w ujęciu Franciszka Ksawerego Arnolda. Problem zasady formalnej teologii pastoralnej, Lublin 1965 (ArKUL). Nieprzeciętnym streszczeniem tej pracy jest opracowanie, które znalazło swe miejsce w pracy zbiorowej Theologie im Wandel, opublikowanej z racji stupięćdziesięciolecia powstania Wydziału Teologicznego na Uniwersytecie Tybińskim: F. Blachnicki, Das Prinzip des Gott-menschlichen als Formalprinzip der Pastoraltheologie, w: Theologie im Wandel. Festschrift zum 150 Jährigen Bestehen der katholisch-theologischen Fakultät an der Universität Tübingen. Schriftleitung J. Ratzinger, J. Neumann. München-Freiburg i. Br. 1967, s. 631-659 (tł. polskie: TPO I, s. 447-473).

51 F. Blachnicki, M. Marczewski, Wprowadzenie do wspótczesnej teologii pastoralnej, s. 43-47. Tybiński Pastoralista był jednym spośród teologów, który wprowadził w tok swej refleksji zasady personalizmu. Uważał mianowicie, że proces zbawczy, który dokonuje się pomiędzy Bogiem a człowiekiem, powinien posiadać znamiona struktury międzyosobowego dialogu: „Pośrednictwo zbawcze Kościoła, duszpasterstwo, winno respektować ten podstawowy charakter procesu zbawczego; winno mu służyć. Jego celem jest umożliwienie, aktualizowanie i ułatwianie osobowego spotkania Boga i człowieka" (TPO I, s. 456). 
i synergistycznym; - Chrystus umocowuje instrumentalny i ministerialny charakter kościelnego pośrednictwa zbawczego; - Życie chrześcijańskie powinno być zorientowane chrystocentrycznie. Ojciec stanowi cel tego życia, a Chrystus jest drogą do Niego. Z tej racji chrześcijaństwo posiada nie tylko charakter chrystocentryczny, ale i teocentryczny; - Pośrednictwo Chrystusa wskazuje także na jego eklezjologiczny wymiar. Chrystus jako Nowy Adam jednoczy zbawionych i w misteryjny sposób łączy ich społecznie, tworzy swe mistyczne Ciało, Kościół, który wraz z Nim i w jedności Ducha Świętego pełni funkcje pośredniczącą. Cały Kościół, jako »societas sanctorum « i zarazem "societas sanctificans", realizuje posłannictwo zbawcze; - Zakorzenienie chrystologiczne pozwala Księdzu Arnoldowi na wykazanie związku, jaki jawi się w historii Kościoła pomiędzy obrazem Chrystusa a ujęciem duszpasterstwa i duchowości chrześcijańskiej ${ }^{52}$.

b. Punkt wyjścia tego ujęcia stanowi przyjęcie personalizmu, który wyjaśnia, na przykład w teologii, relacje zachodzące pomiędzy Bogiem a człowiekiem. Dokonując analizy przemyśleń tybińskiego Pastoralisty, Ksiądz Blachnicki podjął próbę „głębszego uzasadnienia dialogicznego charakteru procesu zbawczego w świetle fenomenologii i teologii osoby"53, a następnie wykazał, że pośrednictwo zbawcze „wynika z samej natury osoby i międzyosobowego spotkania i że należy ono do istotnych warunków umożliwiających zaistnienie osobowego dialogu pomiędzy Bogiem a człowiekiem"54, dzięki konstytutywnym elementom zbawczego spotkania z Bogiem: słowa, wiary i sakramentu ${ }^{55}$. Te analizy pozwoliły mu na wypracowanie i sformułowanie personalistycznej zasady duszpasterstwa: „Pośrednictwo zbawcze Kościoła, czyli duszpasterstwo, musi być sprawowane w tym celu i w taki sposób, żeby aktualizować osobowe spotkanie z Bogiem w wierze poprzez słowo i sakrament" ${ }^{\text {56. }}$.

c. Wprowadzenia »zasady personalistyczno-dialogicznej« dokonał Sługa Boży w wyniku zakwestionowania schematu myślowego Księdza Arnolda, który dokonując analizy sytuacji duszpasterskiej „w świetle dialektycznych przeciwieństw pomiędzy antropocentryzmem a teocentryzmem, postulował harmonijne wyrównanie obu przeciwstawnych postaw w syntezie bosko-ludzkiego synergizmu" 57 . Ksiądz Blachnicki podjął próbę naświetlenia antropocentryzmu, teocentryzmu i synergizmu „z punktu widzenia poglądów filozoficzno-teologicznych, dotyczących relacji moralności do religii, etosu do misterium, wartości dobra do wartości świętego [...], odniesień natury do łaski”58. Rezultatem przezwyciężenia antro-

\footnotetext{
52 F. Blachnicki, Das Prinzip des gott-menschlichen als Formalprinzip der Pastoraltheologie, s. 644-646.

53 Tenże, Pośrednictwo zbawcze Kościoła w ujęciu Franciszka Ksawerego Arnolda, s. 41.

54 Tamże s. 48; F. Blachnicki, Słowo - wiara - sakrament, WdL, s. 35-56.

55 F. Blachnicki, Pośrednictwo zbawcze Kościoła w ujęciu Franciszka Ksawerego Arnolda, s. 141.

56 Tamże.

57 Tamże, s. 216.

58 Tamże, s. 180.
} 
pocentryzmu było wypracowanie - opisanej wyżej - personalistycznej zasady duszpasterstwa ${ }^{59}$. Natomiast bliższe zapoznanie się z rozumieniem pojęcia "przesadnego « lub »skrajnego teocentryzmu«w refleksji teologiczno-filozoficznej Księdza Arnolda, pozwoliło Słudze Bożemu na ustalenie, że nie chodzi tu w istocie o teocentryzm, lecz „apersonalistyczną koncepcję procesu i pośrednictwa zbawczego”, co w konsekwencji umożliwiło na wyprowadzenie wniosku, że „wszystkie ukazywane przez Arnolda cechy teocentryzmu teologicznopastoralnego można (...) pojąć jako postulaty personalistycznej koncepcji stosunku Boga do człowieka" ${ }^{\prime 60}$. W miejsce dialektycznych przeciwieństw między antropocentryzmem a teocentryzmem i wyrównania obu przeciwstawnych postaw w syntezie bosko-ludzkiego synergizmu, Ksiądz Blachnicki przedstawił "personalistyczno-dialogiczne« ujęcie relacji Boga do człowieka w procesie i pośrednictwie zbawczym ${ }^{61}$ i postawił pod znakiem zapytania słuszność sformułowania »zasada bosko-ludzka«, wypracowanego przez tybińskiego Teologa, zastępując je określeniem »zasada personalistyczno-dialogiczna«.

d. Ksiądz Blachnicki dokonując analizy i krytyki prac Księdza Profesora Arnolda, zdawał sobie doskonale sprawę z tego, że ma do czynienia $\mathrm{z}$ "genialną intuicją i niezwykle skrzętną pracą badawczą” uczonego, dzięki której „teologia pastoralna jako dyscyplina zyskała teologiczną i naukową metodę, instrument, dzięki któremu można oceniać duszpasterską działalność współczesnego Kościoła w myśl pewnych i powszechnie obowiązujących kryteriów" ${ }^{62}$. W trakcie lektury tezy doktorskiej Sługi Bożego łatwo można zauważyć troskliwą i głęboką analizę myśli Tybińczyka, mającą na celu udoskonalenie tego instrumentu tak, aby nie potrzebował już więcej uzupełnień, pogłębień i sprecyzowań. Dlatego po wprowadzeniu „propozycji formalno-strukturalnych” oraz uzupełnieniu ich przez włączenie „podstaw treściowych, trynitarno-chrystologicznych"63 otrzymała nazwę "zasady personalistyczno-chrystologicznej teologii pastoralnej i duszpasterstwa«. Eliminuje ona - ze względu na znamiona ujęcia integralnego - poprzednio wypracowane przez Księdza Blachnickiego koncepcje, a mianowicie "zasadę chrystologiczną", »zasadę personalistyczną» i»zasadę personalistyczno-dialogiczną«. Ta nowa formuła brzmi następująco: „zbawcze pośrednictwo Kościoła (jako instytucji), czyli duszpasterstwo, musi być sprawowane w tym celu i w taki sposób, aby uobecnić samoudzielanie się Boga w Chrystusie przez słowo i sakrament oraz warunkować wolne przyjęcie tego samoudzielania się w Duchu Świętym przez wiarę i miłość dla wzrostu Kościoła (jako społeczności)" ${ }^{\prime 4}$.

\footnotetext{
59 Tamże, s. 210.

60 Tamże, s. 211, 214.

61 Tamże.

62 F. Blachnicki, Das Prinzip des gott-menschlichen als Formalprinzip der Pastoraltheologie, s. 647.

63 Tenże, Pośrednictwo zbawcze Kościoła w ujęciu Franciszka Ksawerego Arnolda, s. 299. Dokonał tego w rozdziale czwartym przywołanej dysertacji: Chrystus - pośrednik a pośrednictwo zbawcze Kościoła (s. 218-293).

64 Tamże, s. 299.
} 
Podstawą dla pierwszego etapu refleksji pastoralnoteologicznej Księdza Blachnickiego okazał się dorobek Księdza Profesora Arnolda ${ }^{65}$, a dla drugiego - rozprawa habilitacyjna ${ }^{66}$. W każdej z nich Ksiądz Blachnicki zawarł swoiste ujęcie zasady teologii pastoralnej i opartego na niej duszpasterstwa. Dla pierwszej zasadą okazał się "personalizm chrystologiczny«, dla drugiej: »koinōnia (»communio«, wspólnota), która w wiele lat później została określona mianem »eklezjologii communio « ${ }^{67}$.

Dla tej refleksji pastoralnoteologicznej istotne okazuje się ustalenie zalecności, jakie istnieją dla dwóch prócz wspólnoty "wiodących « ujęć Kościoła, a mianowicie ludu Bożego i sakramentu. Ksiądz Blachnicki rozstrzyga, że „wspólnota jest tą rzeczywistością, którą oznacza obraz ludu Bożego oraz której realizowanie i osiąganie jest jego zadaniem i celem" ${ }^{68}$. Gdy chodzi o określenie Kościoła mianem sakramentu, to nieoczekiwanie nadaje ono pojęciu wspólnota charakter rzeczywisty i wzajemnie wyjaśniający: „Idea wspólnoty wyjaśnia dopiero właściwą treść idei Kościoła - sakramentu, a [...] pojęcie sakramentu określa, w jakim sensie Kościół jest wspólnotą ${ }^{69}$. Oznacza to, że „Kościół o tyle jest sakramentem zbawienia, o ile jest wspólnotą, o ile istnieje i urzeczywistnia się w prawdziwej wspólnocie”. I odwrotnie: „Tam, gdzie powstaje i aktualizuje się rzeczywista wspólnota ludzi

${ }^{65}$ F. Blachnicki, Pośrednictwo zbawcze Kościoła w ujęciu Franciszka Ksawerego Arnolda. Problem zasady formalnej teologii pastoralnej, Lublin 1965 (ArKUL).

${ }^{66}$ Eklezjologiczna dedukcja teologii pastoralnej (Lublin 1971). Wydana jako druga część Teologii pastoralnej ogólnej.

67 „Przyjmuje się powszechnie, że według Vaticanum II komunia Kościoła jest w swej istocie realizacją pierwotnej stwórczej wspólnoty z Bogiem, która znalazła swe doskonałe spełnienie w Jezusie Chrystusie i jest w gruncie rzeczy uczestnictwem w komunii trynitarnej. Jest to teandryczna wspólnota tych, którzy mają udział w wewnątrztrynitarnym życiu Boga. Poszczególne elementy takiego spojrzenia na Kościół rozsiane są w różnych miejscach soborowego nauczania. W Lumen gentium ojcowie Soboru stwierdzają, że "przedwieczny Ojciec, na skutek najzupełniej wolnego i tajemnego zamysły swej mądrości i dobroci, stworzył świat cały, a ludzi postanowił wynieść do uczestnictwa z życiu Bożym « (KK 2). Gdy człowiek zaprzepaścił tę wspaniałą możliwość, Bóg go nie opuścił; przez wzgląd na Chrystusa, "pierworodnego wszelkiego stworzenia« (Kol 1, 15), postanowił wierzących w Niego zgromadzić w Kościele świętym (por. KK 2) [...]. »[Duch Święty] prowadząc Kościół do wszelkiej prawdy (por. J. 16, 13) i jednocząc we wspólnocie (in communione) i w posłudze, uposaża go w rozmaite dary hierarchiczne i charyzmatyczne, i przy ich pomocy nim kieruje oraz owocami swoimi go przyozdabia (por. Ef 4, 11-12; 1 Kor 12, 4; Ga 5, 22). Mocą Ewangelii utrzymuje Kościół w ciągłej młodości, ustawicznie go odnawia i do doskonałego zjednoczenia z Oblubieńcem prowadzi« (KK 4). Jako taki jest równocześnie i pierwszym Budowniczym i ostatecznym Gwarantem jedności eklezjalnej komunii. Od wewnątrz ją urzeczywistnia i rozszerza (DM 4). W ten sposób dochodzi się do zasadniczego wniosku, że Kościół jako komunia mających udział w trynitarnym życiu Boga, jest darem Trójjedynego. Dlatego ojcowie Soboru przytaczają słowa św. Cypriana z Kartaginy: "Tak to cały Kościół okazuje się jako »lud zjednoczony jednością Ojca, Syna i Ducha Świętego" (O modlitwie Pańskiej 23) « (KK 4)” (A. Czaja, »Communio« w eklezjologii Soboru Watykańskiego II i w dokumentach posoborowych, w: „Communio" w chrześcijańskiej refleksji o Kościele, red. A. Czaja, M. Marczewski, Lublin 2002, s. 112-113).

68 TPO II, s. 193.

69 Tamże, s. 194. 
z Bogiem i pomiędzy sobą w Chrystusie i Duchu Świętym, tam równocześnie powstaje i zaczyna istnieć Kościół jako sakrament jedności i zbawienia"70. Sługa Boży zauważa jeszcze jedno ważne dobro, jakie wynika powiązania wspólnoty i sakramentu: Pojęcie sakramentu określa, w jakim sensie Kościół jest wspólnotą. Do pojęcia wspólnoty, jaką jest Kościół, dodaje coś istotnego, czego nie można z niego wyprowadzić, a mianowicie, że jest wspólnotą eschatologiczną. Utrzymuje również, że „nie wystarczy już mówić: „Kościół jest wspólnotą«, lecz trzeba tę rzeczywistość określić precyzyjnie: »Kościół jest wspólnotą - sakramentem albo sakramentem wspólnoty «" ${ }^{\prime 1}$.

Tak zarysowany obraz Kościoła jako wspólnoty oraz Kościoła jako sakramentu wspólnoty zawiera w sobie wewnętrzną jedność, jaka istnieje pomiędzy jej wymiarem wertykalnym i horyzontalnym, tworząc z Kościoła braterską wspólnotę wierzących ${ }^{72}$, wspólnotę charyzmatów i wynikających z nich posług (służb) ${ }^{73}$, która

70 Tamże, s. 199. Stwierdzenie to jednocześnie wskazuje na cel posługi zbawczej. Jeśli bowiem celem działalności Kościoła (pełnienia przez niego posługi zbawczej) jest urzeczywistnianie się Kościoła, to „W świetle powyższego ujęcia istoty Kościoła jako sakramentu wspólnoty [...] będzie to równoznaczne z realizowaniem prawdziwej, autentycznej, a więc osobowej wspólnoty ludzi z Bogiem i pomiędzy sobą" (tamże, s. 200).

${ }^{71}$ Tamże, s. 205. W przekonaniu Sługi Bożego art. 9 Konstytucji dogmatycznej o Kościele jest wymownym potwierdzeniem, jak te trzy określenia Kościoła: ludu Bożego, sakramentu i wspólnoty przenikają się, uzupełniają, odnajdując we wspólnocie właściwe i jedyne określenie Kościoła, „które nie jest tylko obrazem, ale wyraża wprost samą rzeczywistość oznaczaną przez te obrazy. Dlatego [...] domagają się wyjaśnienia poprzez ideę wspólnoty”. Ksiądz Profesor Czesław S. Bartnik wprowadza w ten tok rozumowania ważna uwagę: „[...] rozgorzał spór, czy koinonia może być samodzielnym określeniem Kościoła [...]. Jeśli »wspólnotę« rozumieć tylko jako atrybut, czyli »jedność«, »wspólność«, »związanie w całość«, to nie może ona »definiować« Kościoła, bo może się odnosić do każdego zbioru ludzi czy rzeczy, jak transcendentale, i nie oddaje specyfiki Kościoła [...]. Jeżeli natomiast »wspólnota " nie stanowi skrótu, lecz występuje wraz ze specyfikującą ją treścią, np. »wspólnota w Chrystusie«, to może być stosowana w eklezjologii i w tym można zgodzić się z Janem Pawłem II, F. Blachnickim, W. Hryniewiczem, A. Nosolem, L. Balterem i innymi, że oddaje ona Kościół. W tym sensie Synod Biskupów z 1985 r. mówił o»eklezjologii komunii«. Sobór określa Kościół przez »wspólnotę« zawsze z dopełnieniem treściowym, np.: »Chrystus ustanowił swój Kościół święty, wspólnotę (communio) wiary, nadziei i miłości tu na tej ziemi jako widzialny organizm « (KK 8)" (Bartnik D II, s. 40). Zob. M. Marczewski, Kościót jest sakramentem wspólnoty. (Ks. Franciszek Blachnicki 1921-1987), w: »Communio« w chrześcijańskiej refleksji o Kościele, red. A. Czaja, M. Marczewski, Lublin 2002, s. 161-188.

72 TPO II, s. 205-255. Kościół wspólnota (sakrament wspólnoty) posiada swe źródło, wzór i zasadę tajemnicy jedności w tajemnicy Trójcy Świętej (DE 2).

73 Tamże, s. 255-282. Zdaniem Sługi Bożego „rewolucyjna wprost zmiana w spojrzeniu na działający apostolsko Kościół, jaka dokonała się na II Soborze Watykańskim, znalazła swoje sformułowanie w artykule 2 Dekretu o apostolstwie świeckich [...]. Odtąd znów w eklezjologii, a konsekwentnie w teologii pastoralnej możemy mówić o apostolskiej sukcesji całego Kościoła, [a także], że w Kościele istnieje tylko jedna misja i jeden apostolat, w którym uczestniczy cały lud Boży" (DA 3; KK 32). Konsekwencją tego jest przyjęcie przez Vaticanum II określonej wizji Kościoła, a mianowicie „wspólnoty działającej, w której każdy ma swoje określone zadanie do spełnienia w służbie całości” 
w sprawowaniu liturgii objawia się i urzeczywistnia jako skuteczny znak Kościoła ${ }^{74}$, objawia Kościół jako »wspólnotę/communio/koinōnia « ${ }^{75}$.

„Pojęcie komunii - by powrócić do dokumentu potwierdzającego teologicznopastoralne rozeznanie Księdza Blachnickiego - znajduje się w»sercu samorozumienia Kościoła«, jako Misterium osobowej jedności każdego człowieka z Trójcą Świętą i z innymi ludźmi, zapoczątkowanej przez wiarę i skierowanej do pełni eschatologicznej w Kościele niebieskim, która w pewnej mierze urzeczywistnia się już w Kościele na ziemi” (Communionis notio, art. 3). Kardynał Ratzinger przyjął „Z zadowoleniem tę nową orientację" i podjął próbę budowania eklezjologii wokół tego centrum. Napisał wprost: „Można bez obawy pobłądzenia powiedzieć, że to pojęcie zawiera w sobie eklezjologiczną syntezę, łączącą w sobie wypowiedzi o Kościele z wypowiedziami o Bogu oraz o życiu Bogiem i z Bogiem - syntezę, która uwzględnia wszystkie intencje eklezjologii Drugiego Soboru Watykańskiego, w ich wzajemnych odniesieniach"76.

Termin koinonia (communio, wspólnota) Sługa Boży rozumiał w sensie biblijno-teologicznym, to znaczy jako „rzeczywistość nadprzyrodzoną, która zaistniała w tym świecie i stała się obecną z chwilą zesłania Ducha Świętego przez zmartwychwstałego i uwielbionego Chrystusa" "77. Zdając sobie sprawę ze zwięzłości tego określenia, podjął próbę przedstawienia istotnej treści tego pojęcia koinōnia ${ }^{78}$, by uzasadnić tezę, że wspólnota, którą tworzy Duch Święty, może być uznana za zasadę życia Kościoła ${ }^{79}$, zasadę jego działania ${ }^{80}$ i zasadę teologii pastoralnej jako teologii tego życia ${ }^{81}$. Konstatacje te przybrały formę trzech odrębnych zasad (formuł):

(KK 4), a więc wspólnoty charyzmatów i wynikających z nich służb, gdzie urząd jest gwarantem jego służebnego charakteru (diakonat) i jedności wspólnoty (biskupi, prezbiterzy).

${ }_{74}$ TPO II, s. 282-311. To znaczenie liturgii podkreśla, według Sługi Bożego, Konstytucja o liturgii świętej w art. 2, 26, 41: „Liturgia w ujęciu Soboru jest sakramentem Kościoła, podobnie jak Kościół jest sakramentem Boga, pragnącego zjednoczyć ze sobą i pomiędzy sobą rodzaj ludzki. Albo mówiąc jeszcze inaczej: liturgia jest jakąś formą aktualizowania się Kościoła, podobnie jak tą formą jest Kościół lokalny (tamże s. 284-285).

75 Cz. Krakowiak, Liturgia epifaniq »eklezjologii communio«, w: In Persona Christi. Ksiegga na 80-lecie Księdza Profesora Czesława S. Bartnika, t.1, red. K. Góźdź, Lublin 2009, s. 947-960.

76 J. Ratzinger, Eklezjologia Konstytucji »Lumen gentium«, w: Kościót. Pielgrzymująca wspólnota wiary, red. S. O. Horn, V. Pfnür, Kraków 2005, s. 116, 118. Zob. J. Ratzinger, Gemeinde aus der Eucharistie, w: 800 Jahre St. Martini Münster. Hrsg. W. Hülsbusch, Münster 1980, s. 32-34; tenże. "Communio«- ein Program, Com 21(1992), s. 454-463; tenże, Duch Święty jako "Communio«, w: Kościót. Pielgrzymująca wspólnota wiary, s. 33-52; tenże, Eklezjologia Konstytucji „Lumen gentium «, tamże, s.111-137; tenże, »Communio«. Eucharystia - wspólnota - posłanie, tamże, s. 53-79.

77 TPO II, s. 439.

78 Zajmuje ona znaczącą część trzeciego rozdziału pracy habilitacyjnej: TPO II, s. 345-417; tenże, Wyjaśnienie pojęcia »koinōnia«, w: Biblioteczka animatora, z. 1, s. 34-64.

79 TPO II, s. 439-444.

80 Tamże, s. 445-455.

81 Tamże, s. 423-438. 
- Zasada życia Kościoła określającą, w jaki sposób ma się on urzeczywistniać zgodnie z wolą Chrystusa i swoją naturą, dla zapewnienia sobie wewnętrznego i zewnętrznego wzrostu, jest koinōnia, czyli w widzialnym znaku (sakramentalnie) posługi słowa i sakramentu oraz społecznej jedności wiary i miłości jest zrealizowana wspólnota życiowa osób z Chrystusem i pomiędzy sobą w Duchu Świętym, który jako jedna i ta sama Osoba w Chrystusie i wszystkich członkach Kościoła stanowi niewidzialną istotę tej wspólnoty ${ }^{82}$;

- Pośrednictwo zbawcze Kościoła należy sprawować w tym celu i w taki sposób, aby uobecniać samooddanie się Boga w Chrystusie w słowie i sakramencie, i warunkować wolne przyjęcie tego oddania się we wzajemnym oddaniu siebie w Duchu Świętym przez wiarę i miłość, dla urzeczywistniania wspólnoty w aspekcie wertykalnym (z Bogiem) i horyzontalnym (z braćmi), w widzialnym i skutecznym znaku zgromadzenia eucharystycznego i wspólnoty lokalnej, pozostającej w jedności z Kościołem powszechnym ${ }^{83}$;

- Teologia/Eklezjologia pastoralna jest teologiczno-praktyczną nauką, która $\mathrm{w}$ świetle Objawienia oraz zbawczej woli Boga (obiectum formale quo) zajmuje się żywym Kościołem, czyli Kościołem, o ile urzeczywistnia się współcześnie we wspólnocie (obiectum formale quod) ${ }^{84}$.

Wypracowanie zasady teologii pastoralnej skoncentrowanej wokół pojęcia "wspólnota " nastąpiło na wiele lat wcześniej niż orzeczenie biskupów o»eklezjologii communio « podczas II Nadzwyczajnego Zgromadzenia Generalnego Synodu Biskupów w 1985 r. W ślad za nim w liście Kongregacji Nauki Wiary Communionis notio przedstawiono ramy katolickiego rozumienia komunii Kościoła ${ }^{85}$, a św. Jan Paweł II Liście apostolskim »Novo millennio ineunte« na zakończenie wielkiego jubileuszu roku 2000, zwrócił się z gorącym apelem, by „Czynić Kościół domem i szkoła komunii: oto wielkie wyzwanie, jakie czeka nas w rozpoczynającym się

\footnotetext{
82 Tamże, s. 444. Jeśli porównamy personalistyczno-chrystologiczna zasadę formalną teologii pastoralnej i duszpasterstwa z zaproponowaną powyżej koinonostyczno-pneumatologiczna zasadą formalną działania Kościoła, to pierwsza „nie została w niczym zakwestionowana”, zaś druga została „wzbogacona o nowe aspekty związane z pojęciem koinōnia oraz pojęciem pneumatologicznego porządku pośrednictwa zbawczego" (tamże, s. 454).

83 Tamże, s. 454-455. Prócz formuły rozwiniętej Sługa Boży podaje formę skróconą: „Zasadą życia i działania Kościoła jest w Duchu Świętym oraz w widzialnym i skutecznym znaku urzeczywistniona koinōnia w aspekcie wertykalnym i horyzontalnym" (tamże, s. 455).

84 Tamże, s. 467.

${ }^{85}$ List do biskupów Kościoła katolickiego O niektórych aspektach Kościoła pojętego jako komunia: "Communionis notio" [ z 28 V 1992 r.], w: W trosce o petnię wiary. Dokumentu Kongregacji Nauki Wiary 1966-1994, tł. i oprac. Z. Zimowski, J. Królikowski, Tarnów 1995, s. 390-401.
} 
tysiącleciu, jeśli chcemy pozostać wierni Bożemu zamysłowi, a jednocześnie odpowiedzieć na najgłębsze oczekiwania świata” (art. 43).

\section{Deuterokatechumenat}

Sługa Boży ks. Franciszek Blachnicki, tworząc system naukowej refleksji pastoralnoteologicznej, skoncentrowany wokół pojęcia wspólnoty (communio, koinōnia), zdawał sobie sprawę z tego, że może stać się on kolejnym teoretycznym programem. Dlatego znamy go jako założyciela Ruchu Światło-Życie ${ }^{86}$, który wyrósł na gruncie tej właśnie eklezjologiczno-pastoralnej syntezy i który jest "przełożeniem« teorii na praktykę życia parafialnego. Od początku bowiem, gdy bada się historię Ruchu, był i jest mocno związany z parafią i najważniejszym wydarzeniem, centrum, życia parafialnego - Eucharystią poprzez fakt, że dzieci i młodzież stanowią służbę liturgiczną ołtarza, a małżonkowie - Kościół domowy ${ }^{87}$.

Zdając sobie sprawę ze stanu współczesnego katolicyzmu polskiego w ogóle a sytuacją, w jakiej znajdują się polskie parafie - w szczególności - uważał, że przekształcenie parafii w parafię wspólnotę można dokonać tylko przy pomocy małych wspólnot ${ }^{88}:$ „Parafia jako instytucja, jako pewna organizacja jest konieczna, ale ona sama z siebie nie może stać się źródłem odnowy Kościoła. Sprawcą odnowy jest Duch Święty, a tam, gdzie działa Duch Święty, powstaje ruch. Duch Święty działa przez organizację Kościoła, przez urząd, przez wszystko, co należy do struktury Kościoła, ale działanie to nie może być nigdy jednostronne. Obok działania administracyjnego musi być działanie oddolne. Dopiero to działanie napełnia struktury życiem. Sama obiektywna struktura Kościoła oparta na woli Chrystusa jest pewnym światłem, drogowskazem, ale to musi wcielać się w życie. Życia zaś nie można odgórnie zaprogramować. Dlatego powstają różne ruchy charyzmatyczne, ruchy odnowy w Duchu, które wnoszą życie [...]. W ten sposób ruchy z natury swej charyzmatyczne [...] po pewnym okresie szukania, są coraz bardziej ukierunkowane na parafie, na wspólnoty lokalne i tam znajdują swoje miejsce, swoją właściwa rolę" 89 .

\footnotetext{
86 R. Derewenda, M. Marczewski, Światło-Życie, ruch, EK XIX, s. 332-335.

87 Ten rys Ruchu Światło-Życie wymownie podkreślił to kard. Karol Wojtyła 5 XII 1976 r. podczas spotkania jego przedstawicieli z Komisją ds. Apostolstwa Świeckich, której był przewodniczącym: „Ruch ten, ruch oazowy pozostaje w jakimś szczególnym stosunku do całego Kościoła w Polsce, z niego wyrasta i do niego chce wracać, jemu chce służyć; pozostaje w stosunku do Kościoła rozumianego najszerzej i w stosunku do Kościoła rozumianego w sposób najbardziej konkretny, to znaczy do parafii (...). Ruch wychodzi z tych struktur realnych, konkretnych, odwiecznych, tych wspólnot, które składają się na Kościól, a także z parafii i chce do nich wracać" (F. Blachnicki, Godziny Taboru, Carlsberg-Lublin 1989, s. 81; skrót: GT).

${ }^{88}$ F. Blachnicki, Parafia wspólnota - wspólnoty w parafii, w: Biblioteczka animatora, zeszyt 1: Koinōnia. Kościół wspólnota - wspólnoty w Kościele, s. 95.

89 GT, s. 58-59.
} 
Ruchy eklezjalne tylko wtedy spełnią swe zadanie, gdy za zasadę życia Kościoła i cel jego zbawczej posługi uznają wspólnotę, a parafię za »wspólnotę wspólnot«: „Kościół musi stać się widzialny jako wspólnota w konkretnej formie parafii”90.

Na proces budowania wspólnoty, czyli urzeczywistniania się Kościoła we wspólnocie, w przekonaniu Sługi Bożego, składają się trzy etapy: (a) ewangelizacja, (b) inicjacja (katechumenat/deuterokatechumenat), (c) diakonia.

a. Należy rozpocząć „od położenia fundamentu, którym jest spotkanie osobowe z Chrystusem i zjednoczenie z Nim przez wiarę, a więc to, co stanowi istotę communio w wymiarze wertykalnym, inaczej mówiąc: od ewangelizacji" ${ }^{\prime 1}$, którą rozumie jako „pierwsze głoszenie Chrystusa w celu doprowadzenia do osobowego przyjęcia Go przez wiarę jako swojego Zbawiciela i Pana"92. Z procesem ewangelizacji Sługa Boży łączy proces wyzwolenia. To bardzo ważne powiązanie, które posiada znaczenie wychowawcze. Chodzi o wyzwolenie rozumiane jako oswobodzenie się z jarzma grzechu i wszelkich zniewoleń (alkoholizm, nikotynizm, narkomania) i uzależnień będących jego bezpośrednim lub pośrednim skutkiem ${ }^{93}$. W wychowawczym procesie Ruchu Światło-Życie wyzwolenie wiąże się z programem Krucjaty Wyzwolenia Człowieka ${ }^{94}$. Ewangelizacja musi być przeżywana i realizowana jako wyzwolenie, a pomiędzy tymi pojęciami zachodzi wewnętrzny związek i zależność. Nie można oddzielić akcji na rzecz wyzwolenia człowieka od ewangelizacji, gdyż u ich podstaw leży proces tworzenia nowego człowieka ${ }^{95}$, który stanowi przewodnią ideę wychowawczą w Ruchu Światło-Życie: „Budować wspólnotę eklezjalną, Kościół wspólnotę, oznacza więc zainicjowanie przez ewangelizację konkretnych procesów wyzwoleńczych w danym człowieku i środowisku. Musi nastąpić konfrontacja ewangelicznej wizji człowieka i międzyludzkiej wspólnoty z przejawami i formami aktualnego zniewolenia"96.

\footnotetext{
90 Tenże, Parafia wspólnota - wspólnoty w parafii, s. 93.

91 Tenże, Istotne cechy ruchu eklezjalnego, w: tenże, Charyzmat »Światło-Życie«, red. G. Wilczyńska, 1987, s. 20.

92 Tamże. Proces ewangelizacji określa Ksiądz Blachnicki fundamentem. Oznacza to, że wszelkie budowanie wspólnoty eklezjalnej bez położenia tego fundamentu byłoby budowaniem na piasku, a nie na skale (Łk 6, 46-49). Wypływa stąd przekonanie, że „trzeba ciągle wracać do ewangelizacji nawet chrześcijan, a więc ludzi już ochrzczonych i w pewien sposób praktykujących, jeżeli ich wiara nie ma jeszcze charakteru communio, czyli osobowego spotkania i zjednoczenia w Chrystusem, Zbawicielem i Panem" (tamże).

93 Tamże, s. 21.

94 F. Blachnicki, Cztery rozważania o wyzwoleniu, w: tenże, Prawda - Krzyż - Wyzwolenie. Ku polskiej teologii wyzwolenia, Carlsberg 1965, s. 37- 74.

95 Tenże, Ruch Światło-Życie jako pedagogia Nowego Człowieka, w: tenże, Charyzmat »Światło -Życie«, red. G. Wilczyńska, 1987, s. 103-124; M. Marczewski, Eklezjologia pastoralna a pedagogika chrześcijańska, w: Wychowanie chrześcijańskie: między tradycją a współczesnością, red. Alina Rynio, Lublin 2007, s. 244-254.

96 F. Blachnicki, Istotne cechy ruchu eklezjalnego, s. 21.
} 
b. Kolejny etap procesu budowania wspólnoty Sługa Boży związał z inicjacją, czyli wprowadzaniem do życia we wspólnocie. Proces inicjacji odgrywa w Kościele podwójną rolę. Wprowadza w życie wspólnoty i zarazem służy jej budowaniu. W Tradycji chrześcijańskiej znalazł swój instytucjonalny wyraz w katechumenacie ${ }^{97}$, który w dokumentach soborowych, a następnie w praktyce Kościoła posoborowego został na nowo wprowadzony i doceniony. Sługa Boży był jednym z nielicznych duszpasterzy, którzy dostrzegli w Ordo initiationis christianae adultorum, ,jeden z najważniejszych dokumentów posoborowej odnowy liturgii [...], bo są w nim nie tylko wskazania dotyczące samego katechumenatu, ale także konkretne sugestie duszpasterskie. W kilku miejscach [bowiem] powiedziano wyraźnie, że na podobieństwo katechumenatu trzeba przeprowadzić różne formy pracy duszpasterskiej nad młodzieżą, [a także] sugeruje się różne formy katechumenatu młodzieżowego, nawet dziecięcego. Chodzi o to, żeby tradycyjną katechezę rozbudować $w$ kierunku katechumenatu, żeby były wszystkie elementy stawania się

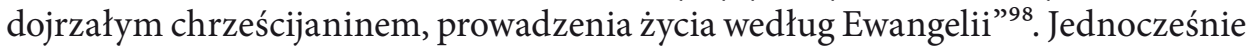
sformułował sześć celów formacyjnych katechumenatu, które mają wykształcić w osobie ludzkiej określone postawy życiowe. Cele katechumenatu są następujące: Wprawianie do życia słowem Bożym, traktowanym jako słowo życia; Przyuczanie do życia modlitwy pojętej jako osobiste spotkanie z Bogiem; Wychowanie do liturgii sakramentalnej, zwłaszcza Eucharystii, jako stałego elementu życia chrześcijańskiego; Doprowadzenie do metanoi, czyli przemiany wewnętrznej człowieka cielesnego w człowieka nowego; Dawanie świadectwa; Wdrażanie do życia we wspólnocie, przez przyjęcie odpowiedzialności za wspólnotę, przyjęcie jakiejś służby, diakonii w oparciu o posiadany charyzmat ${ }^{99}$. W jego przekonaniu dopiero tacy chrześcijanie, którzy przeszli formację katechumenalną i doszli do dojrzałości wiary, stają się wraz z duszpasterzem parafii jej podmiotem czy też zespołem duszpasterzy zdolnym podjąć dzieło ewangelizacji wobec innych (ewangelizacja - katechumenat - nowa parafia) i w ten sposób tworzyć nowy obraz czy nową koncepcję parafii jako wspólnoty wspólnot.

Formację katechumenalną w Ruchu Światło-Życie jego Założyciel określił mianem »deuterokatechumenatu«, w odróżnieniu od właściwego katechumenatu, katechumenatu w sensie ścisłym oraz odróżnienia od neokatechumenatu, to znaczy nazwy konkretnego ruchu, który powstał na Zachodzie Europy ${ }^{100}$.

Ksiądz Blachnicki uznał odnowę katechumenatu za priorytetowe zadanie w życiu współczesnego Kościoła, które zdecyduje o jego przyszłości, a nawet skłaniał się ku »katechumenackiej« koncepcji duszpasterstwa, postulując, by z instytucji katechumenatu „odczytać i przejąć podstawowe prawa życia i rozwoju wspólnoty

\footnotetext{
97 Tamże.

98 Tenże, Ewangelizacja w procesie budowania »nowej parafii«, dz. cyt., s. 87.

99 Tamże, s. 88-89

${ }^{100}$ R. Blázquez, Wspólnoty neokatechumenalne. Ocena teologiczna, Lublin 1989.
} 
chrześcijan"101. Zauważał jednak podstawową trudność, która polega na tym, że „nie można wdrażać do wspólnoty bez istnienia wspólnoty. Wspólnota [bowiem] powinna być właściwym podmiotem procesu inicjacji. Z drugiej strony nie może ona powstać bez katechumenatu, który ją warunkuje ${ }^{102}$. Dlatego ma tu swe miejsce teologia parafii (wspólnoty) i koncepcja katechezy parafialnej i bez podjęcia oraz rozwiązania tego problemu trudno mówić o realizowaniu głównego celu zbawczej posługi Kościoła (budowania Kościoła wspólnoty), który wynika z koncepcji teologii pastoralnej w ogóle. Niewątpliwie, znaczące miejsce w tak rozumianym duszpasterstwie należy przyznać wspólnotom, grupom i ruchom eklezjalnym, w których proces inicjacji deutero- lub neokatechumenalnej będzie realizowany. Nie może być to jednak jedynym rozwiązaniem, co wynika z realistycznej oceny stanu duszpasterstwa w Kościele w Polsce oraz wyrażonej przez Księdza Blachnickiego ponad pół wieku temu zasady: »masy przez elity, elity w służbie mas « ${ }^{103}$, sprowadzającą się dziś do zauważanej szansy bezkonfliktowego przekształcania się »Kościoła ludowego « w»Kościół wspólnotę « ${ }^{104}$.

Postulat pracy formacyjnej w Ruchu Światło-Życie ma także wyraźną wizję punktu docelowego. Sługa Boży określił go mianem „modelu parafii wspólnotowej albo posoborowej”"105, który wypracował dzięki konfrontacji z modelem „parafii tradycyjnej, potrydenckiej, który właściwie jest u nas jeszcze dzisiaj powszechnie podtrzymywany, chociaż znajduje się w stanie permanentnego kryzysu"106. W modelu tym proboszcz stanowi aktywny pomiot, który za wszystko odpowiada $^{107}$. Ma wprawdzie do pomocy określonych ludzi (katecheta, wikariusz(e),

${ }^{101}$ F. Blachnicki, Formacja służby liturgicznej jako jedna z form młodzieżowego deuterokatechumenatu w parafii, w: Biblioteczka animatora. Zeszyt 2: Katechumenat. Wspólnoty formacyjne we wspólnocie lokalnej. s. 59-60). Uzasadnia to następująco: „skoro celem duszpasterstwa jest budo wanie wspólnoty lokalnej, a celem katechumenatu wychowanie i prowadzenie do życia w tej wspólnocie", to można by w sposób zasadny mówić o takiej właśnie koncepcji duszpasterstwa (tamże).

${ }^{102} \mathrm{~F}$. Blachnicki, Istotne cechy ruchu eklezjalnego, s. 21. W tym procesie widział zasadniczą rolę wspólnot, grup i ruchów katolickich w ramach parafii. W nich to każda z osób przeszłaby formację deutero- lub neokatechumenalną, by później wspólnoty te w nawiązaniu do głęboko zakorzenionej w Piśmie św. i tradycji patrystycznej idei Kościoła - Oblubienicy i Matki (Ecclesia Mater) stawały się macierzyńskim łonem rodzącym nowe pokolenia chrześcijan.

${ }^{103}$ Tenże, Ruch Światło-Życie jako pedagogia Nowego Człowieka, dz. cyt., s. 106.

${ }^{104}$ J. Mariański, Kościół w społeczeństwie obywatelskim. Studium socjologiczne, Lublin 1998, s. 131-157.

105 GT, s. 61.

106 Tamże; J. Chrapek, Od potrydenckiego do powatykańskiego modelu parafii, „Koinōnia. Biuletyn Odnowy Parafii" 1(1978), s. 8-26.

${ }^{107}$ Potwierdzają to na przykład badania Pani Profesor Elżbiety Firlit (Parafia rzymskokatolicka $w$ Polsce $w$ okresie transformacji systemowej. Studium socjologiczne, Warszawa 1998): „Większość respondentów świeckich twierdzi, że kierownictwo parafialne spoczywa w rękach proboszcza [...]. Wielu bowiem parafian chciałoby się włączyć czynnie w nurt życia parafialnego - spośród badanych mieszkańców parafii województwa warszawskiego takie pragnienie zgłosiło 24, 2\%, natomiast wśród respondentów z nowosądeckiego było aż 43, 9\% takich osób [...]. Wydaje się, że 
ale nie współdziałają oni z proboszczem „na zasadzie wspólnoty”. Dlatego „temu modelowi - sugeruje Ksiądz Blachnicki - trzeba przeciwstawić inny, który bazuje na soborowej wizji Kościoła. Coraz wyraźniej zarysowuje się model parafii jako wspólnoty, parafii bazującej na cechach organizmu, gdzie są żywe komórki, gdzie wszyscy są podmiotem, a przynajmniej jest tendencja, żeby jak najwięcej ludzi przechodziło z postawy tylko receptywnej i z myślenia o Kościele w kategoriach »oni« na pozycję współuczestnictwa w myśleniu w kategoriach »my«"108.

Model ten opiera się na »koncepcji siedmiu kręgów « ${ }^{109}$, które znakomicie oddają stan i charakter zaangażowania się wiernych chrześcijan w parafii (krąg zewnętrzny -

istotną barierę hamującą podmiotowość laikatu na terenie parafii jest paternalizm księży i ich swoista nadopiekuńczość wobec wiernych, a tym samym brak zaufania do samodzielności świeckich, nieumiejętność traktowania parafian jako partnerów [...]. Mówiąc o barierach utrudniających czynne włączenie się osób świeckich w działalność prowadzona przez parafię należy zwrócić uwagę na komunikację społeczną i system informacji w obrębie parafii [...]. istniejący dotychczas, w wielu parafiach, system komunikacji społecznej i łączności nie realizuje w sposób wystarczający żadnej z tych funkcji. Parafianie często nie wiedzą o istnieniu mikrostruktur parafialnych [...], nie znają zakresu ich działania, nie otrzymują też wystarczających bodźców motywujących ich do aktywnej obecności w parafialnych strukturach. Dodajmy, że w wielu parafiach nie ma struktur poziomych lub istnieją one tylko nominalnie. W konsekwencji, zdecydowana większość parafian jest bierna, konformistyczna, »z zewnątrz sterowana«. Przyzwyczajeni przez lata do roli słuchających, czekają ciągle na inspiracje i wytyczne z zewnątrz. Będąc członkami parafii i czując się emocjonalnie z nią związani, faktycznie pozostają na obrzeżu jej życia wspólnotowego" (s. 297-299). Istnieje jednak i»druga strona medalu «, o której dowiadujemy się z badań Księdza Mariańskiego w cytowanej tu pracy Praktyki religijne $w$ Polsce $w$ procesie przemian. Za wręcz porażające uważam statystyki dotyczące angażowania się katolików polskich w działalność ruchów eklezjalnych, stowarzyszeń czy organizacji katolickich oraz katastrofalnie nikły procent apostolskiego zaangażowania się wiernych w życie parafii (s. 215-251). Pocieszające jest to, jeśli może być to pociechą, że brak zaangażowania się apostolskiego koreluje z brakiem społecznego i obywatelskiego potencjału Polaka. W jakimś momencie naszej tożsamości narodowej doszło do pęknięcia, a następnie rozdarcia tej jedni. Ze wszech miar słuszne jest stwierdzenie Autora: „Brak poczucia sprawstwa w sprawach kraju i pomniejszone poczucie podmiotowości obywateli na poziomie lokalnym koresponduje do pewnego stopnia z poczuciem brak wpływu na sprawy parafii i Kościoła w Polsce, nawet jeżeli pomiędzy tymi dziedzinami życia społecznego nie ma bezpośrednich zależności, a mechanizmy wpływu obywateli i parafian na sprawy publiczne czy parafialno-kościelne są odmienne. Przezwyciężenie deficytów sprawstwa i podmiotowości w obydwu dziedzinach byłoby ważnym czynnikiem motywującym do aktywności obywatelskiej i parafialnej” (s. 244).

${ }^{108}$ GT, s. 61-62. Owo stawanie się Kościoła wspólnoty w konkretnej formie parafii jako wspólnoty wspólnot jest związane nie tylko z eklezjologiczną dedukcją teologii pastoralnej, w myśl której koinōnia stanowi zasadę życia i działania Kościoła (TPO II, s. 438-455), ale również z odkryciem „potęgi żywej komórki” (H.-J. Theysen, Potęga żywej komórki, w: Biblioteczka animatora. Zeszyt 1: Koinonia. Kościół wspólnota - wspólnoty w Kościele, s. 81-85); Die Zelle in Kirche und Welt. Hrsg. von A. Spitaler, Graz-Wien-Köln 1960.

${ }^{109}$ Warto je wymienić, idąc od »centrum«ku "peryferiom«: Diakonia stała konsekrowana wspólnoty lokalnej, Rada apostolska, Wspólnoty apostolskie specjalistyczne, Wspólnoty apostolskie środowiskowe, Wspólnoty formacyjne (deuterokatechumenalne), Wierni praktykujący, Niepraktykujący (krąg misyjny) (GT, s. 64). 
tak zwani chrześcijanie z metryki; krąg praktykujących - tak zwani katolicy $\mathrm{z}$ tradycji, bierni). W tę strukturę parafii „trzeba najpierw wszczepić małe grupy formacyjne", w których ludzie przeżywaliby proces ewangelizacyjno-katechumenalny (katechumenat dorosłych; deuterokatechumenat). Rolę tych grup w strukturze parafii, w przekonaniu Sługi Bożego, winny odegrać grupy oazowe: „Z tych grup, [po odbyciu odpowiedniej formacji], dopiero wywodzą się grupy apostolstwa świeckich [...], gdzie równocześnie ciągle trwa proces formacji, bo on nigdy nie może się skończyć" ${ }^{110}$. Z biegiem czasu proces ten może stać się łatwiejszy, bo na terenie parafii będą istniały wspólnoty żywego Kościoła, które na wzór Świętej Rodziny z Nazaretu samą obecnością będą składać świadectwo wiary, nadziei i miłości.

W świetle tego, co dotychczas przedstawiono, charyzmatem Ruchu Światło-Życie - w kontekście odnowy parafii w Kościele polskim - jest nie tylko wypracowanie odpowiedniej metody kształtowania grup apostolskich (metoda oazy rekolekcyjnej), lecz także diakonia na rzecz parafii, a więc konkretna pomoc (rekolekcje ewangelizacyjne), żeby w każdej parafii mogły takie grupy powstawać i rozwijać się ${ }^{111}$. Osiągnięcie tego celu może dokonać się tylko i wyłącznie poprzez realizację programu ewangelizacyjno-katechumenalnego Ruchu Światło-Życie, a więc konkretnego procesu formacyjnego: „Wszelkie budowanie wspólnoty chrześcijańskiej, także parafii, musi się rozpocząć od doprowadzenia ludzi do wiary w sensie osobistego przyjęcia Chrystusa, osobistego z Nim spotkania [...]. Ten etap budowania wspólnoty chrześcijańskiej łączy się z pojęciem ewangelizacji”112.

\footnotetext{
${ }^{110}$ GT, s. 65.

${ }^{111}$ F. Blachnicki, Charyzmat »Światło-Życie« w służbie odnowy Kościoła lokalnego, w: tenże, Charyzmat »Światło-Życie«, 1987, s. 66-77.

112 Tenże, Ewangelizacja w procesie budowania »nowej parafii«, s. 79. Sługa Boży w jednym z opracowań (F. Blachnicki, Etapy realizacji wspólnotowego modelu parafii. Wizja Ruchu Światło-Życie, „Koinonia. Biuletyn Odnowy Parafii” 2(1979) s. 12-20): wskazał na etapy realizacji wspólnotowego modelu parafii: „Pierwszy etap realizacji wspólnotowego modelu parafii polega na zaszczepieniu wizji parafii jako wspólnoty tym, którzy są za życie parafii odpowiedzialni. Jeżeli proboszcz nie będzie przekonany o konieczności podejmowania pewnych reform, nie podejmie inicjatywy [...]. Nie będzie miał wyostrzonego, krytycznego spojrzenia na braki, niedomagania tradycyjnego modelu życia chrześcijańskiego i życia parafialnego" (s. 13). Chodzi jednocześnie i o to, aby kierujący parafią proboszcz mógł wypracować sobie wizję współczesnego duszpasterstwa ześrodkowanego na budowie parafii jako wspólnoty. Mają mu w tym dopomóc sympozja poświęcone realizacji wspólnototwórczego obrazu parafii, a przede wszystkim udział samego prezbitera w oazie rekolekcyjnej dla kapłanów oraz wysłanie na oazę grup młodzież i dorosłych ze swojej parafii: „Oaza rekolekcyjna jest drogą wypracowania wizji” (s. 16). „Następnym etapem jest ewangelizacja w znaczeniu pierwszej ewangelizacji (...). Ewangelizacja [chodzi tu o tzw. rekolekcje ewangelizacyjne w parafii] zmierza do tego, by parafianie, których mamy, zgromadzić w jedno. Terenem ewangelizacji są parafianie, którzy nie wierzą i nie praktykują - do nich trzeba pójść z Dobrą Nowiną. Ale ewangelizowani muszą być także ci praktykujący tradycyjnie, którzy nie są jeszcze rozbudzeni do żywej wiary” (s. 18-19). „Po ewangelizacji konieczny jest kilkuletni czas pracy w głąb, ale ci ludzie równocześnie muszą już ewangelizować innych. W parafii jest to już zaczyn, ferment [...]. Następny etap to diakonia. Z tych
} 
c. Trzeci etap budowania wspólnoty Sługa Boży związał z pojęciem diakonii. Uważał, że „wspólnota chrześcijańska może istnieć tylko jako wspólnota charyzmatów i służb. Nie można [bowiem] włączyć się do wspólnoty inaczej niż przez zaangażowanie się, niż przez aktualizację swoich charyzmatów, czyli właśnie przez diakonię. W przeciwnym razie dojdziemy do modelu Kościoła podzielonego na pasterzy i owce, na element aktywny i odpowiedzialny oraz pasywny i tylko kierowany, co jest zaprzeczeniem pojęcia wspólnoty, bazującej na my-świadomości wszystkich członków i aktywnej ich współodpowiedzialności”113.

Ksiądz Blachnicki ideę diakonii związał nie tylko z jej rozumieniem jako zasady chrześcijańskiej egzystencji, w myśl której wszystkie funkcje Kościoła i chrześcijan powinny być służebne na wzór Pana (Łk 22, 24-27) ${ }^{114}$, ale i szczególną formą zaangażowania duszpasterskiego pod nazwą »diakonia «.

Na płaszczyźnie parafialnej zobowiązanie Kościoła do służby uwidacznia się w prawie życia każdej wspólnoty, która „podobna do żywej komórki, musi mieć swoje jądro, złożone z grupy ludzi, którzy przyjęli wezwanie Chrystusa do pójścia za Nim, do oddania się całkowitego na Jego służbę w ramach konkretnej wspólnoty. Wśród tych ludzi, obierających drogę naśladowania Chrystusa w dziewictwie i ubóstwie, muszą znajdować się zarówno mężczyźni, jaki i kobiety. Tak było w pierwszej wspólnocie i komórce zgrupowanej wokół Chrystusa i tak musi być do końca pielgrzymowania Kościoła poprzez wieki historii"115. Chodzi więc o powołania do życia, wedle rad ewangelicznych, dla potrzeb wspólnot parafialnych, a nie dla wspólnot zakonnych, „wyjętych«, które żyją częstokroć na marginesie życia Kościoła lokalnego.

Diakonijna koncentracja życia parafialnego jest związana z ewangelizacją i następującym po niej procesem (deutero)katechumenatu, które służą budowaniu parafii wspólnoty wspólnot ${ }^{116}$. Jednym z celów inicjacji (detero)katechumenalnej, jak to już podkreśliliśmy, jest „wdrażanie do życia we wspólnocie przez przyjęcie odpowiedzialności za wspólnotę, przyjęcie jakiejś służby, diakonii opartej na posiadanym charyzmacie"117. Jest to forma diakonii niekoniecznie związana ze szcze-

ludzi, którzy przeżyli przebudzenie przez ewangelizacje, powstaje diakonia, czyli zespół współpracowników w dziele apostolskim" ( s. 19).

${ }^{113}$ F. Blachnicki, Istotne cechy ruchu eklezjalnego, s. 22; TPO II, s. 255-282.

${ }^{114}$ Można wyróżnić, co najmniej trzy jego znaczenia. Pierwsze, w naszym przekonaniu podstawowe, służy opisaniu służby (diakonii) jako fundamentalnego aspektu (zasady) chrześcijańskiej egzystencji, w myśl którego wszystkie funkcje Kościoła i chrześcijan winny być służebne na wzór Pana. Drugim znaczeniem zastępuje się dotychczas określenie posługi charytatywnej (caritas) w triadzie funkcji podstawowych, dzięki którym Kościół aktualnie urzeczywistnia się: martyria, leiturgia, diakonia. Ostatnie ze znaczeń wiąże się z określeniem tym mianem przez Kościół protestancki znaczącej dziedziny duszpasterstwa dobroczynnego, określanego w Kościele katolickim terminem caritas.

115 TPO I, s. 410-411.

${ }^{116}$ GT, s. 51-83; F. Blachnicki, Ewangelizacja w procesie budowania »nowej parafii«, s. 78-91.

117 Tamże, s. 89. 
gólnym rodzajem diakonii, wcielonej we wspólnotę życia rad ewangelicznych, ale podkreślająca raczej istnienie osób świadomych swego służebnego zobowiązania, wynikającego z pójścia za Chrystusem Sługą na podstawie otrzymanego charyzmatu, aby przyczyniać się do powstania żywej wspólnoty lokalnej, do tworzenia razem z duszpasterzem (lub duszpasterzami) zespołu duszpasterzy. Takich diakonii, a więc specjalnych grup posługujących na rzecz parafii (lub struktur ponad parafialnych), może być wiele ${ }^{118}$; one też mogą w przyszłości przyjąć formę "charyzmatu zinstytucjonalizowanego « $\mathrm{w}$ formie przynależenia do określonych organizacji, które wykształciły się (lub wykształcą) w łonie Ruchu Światło-Życie.

W Ruchu Światło-Życie przejście od formacji podstawowej, a więc wypracowanego systemu formacji deterokatechumalnego ${ }^{119}$, do diakonii jest bardzo wyraźne. Stanowi o nim „uczestnictwo w Oazie Rekolekcyjnej Diakonii. Jej celem jest przedstawienie całościowej wizji charyzmatu Ruchu, tak aby po zapoznaniu się z nią i odczy taniu jej jako wezwania, uczestnicy mogli podjąć świadomą decyzję zaangażowania się w Diakonię Ruchu Światło-Życie. Ten sposób partycypacji w charyzmacie Ruchu stanowi równocześnie realizowanie diakonii we wspólnocie Kościoła. Po tej ogólnej decyzji podjęcia kontynuuje się formację diakonijną, która może się dokonywać w ramach Szkoły animatora lub diakonii specjalistycznych"120.

\section{Streszczenie}

Wstępne refleksje nad stanem polskiego duszpasterstwa, współczesną religijnością Polaków oraz możliwością wyjścia z zaznaczającego się coraz bardziej impasu pozwoliły na zakreślenie trzech tematów, którymi warto się zająć: (1) stanem polskiej religijności, (2) konsekwencjami pastoralnymi wynikającymi z wypracowanej przez Ojców Soboru »eklezjologii communio«, (3) oraz "przetłumaczoną« na język pewnego ruchu, pewnego działania, eklezjologią Soboru w jej centralnych elementach: osoby, wspólnoty ludu Bożego,

\footnotetext{
118 „Z perspektywy kilku lat [możemy] popatrzeć na to, jak kolejno z oazy jako źródła wywodzą się różne diakonie. Powstają zatem obok ośrodka centralnego, który organizuje oazy rekolekcyjne, inne ośrodki, inspirujące w terenie grupy, które podejmują się konkretnych zadań, podejmują konkretną diakonię. W tej chwili możemy mówić o sześciu głównych strumieniach, wywodzących się z oazy i stanowiących wyspecjalizowane diakonie [...]. Diakonie są przy tym pomiędzy sobą powiązane w pewien system. Zadania poszczególnych diakonii można ułożyć w kolejności, która odpowiada określonym etapom wzrostu życia chrześcijańskiego we wspólnocie. Sprawa kolejności diakonii nie jest więc rzeczą przypadkową. Obecnie są wyodrębnione następujące diakonie: 1. diakonia wyzwolenia, 2. diakonia ewangelizacji, 3. diakonia deuterokatechumenatu, 4. diakonia liturgii, 5. diakonia Domowego Kościoła, 6. diakonia modlitwy, 7. diakonia wspólnoty lokalnej" (F. Blachnicki. Charyzmat "Światło-Życie»w stużbie odnowy Kościoła lokalnego s. 71). Omówienie każdej z form diakonii: s. 72-75.

${ }^{119}$ Formacja podstawowa służby liturgicznej i Ruchu Światło-Życie. Materiały do szkoły animatora grupy, red. M. Ostrowski, Kraków 1989.

${ }^{120}$ Charyzmat Ruchu Światło-Życie. Próba opisu. Tekst roboczy na Nadzwyczajna Kongregację Odpowiedzialnych 30 IV-3 V 1993, [oprac. B. Badura i in.], Lublin 1993, s. 48.
} 
wspólnoty apostolskiej. Każdy z nich może stanowić przedmiot osobnego studium lub kilku książek. W tym opracowaniu zakreślimy jedynie linie refleksji.

Słowa klucze: charyzmat, (deutero)katechumenat, diakonia, eklezjologia »communio", ewangelizacja, grupy elitarne, indywidualizm, inicjacja, parafia, pluralizm, religijność, Ruch Światło-Życie, teologia pastoralna, wspólnota.

\section{DEM AUFRUF ZUR EVANGELISIERUNG GERECHT WERDEN}

\section{Zusammenfassung}

Die einführenden Überlegungen über den Zustand der polnischen Seelsorge, die heutige Religiosität der Polen sowie die Möglichkeiten eines Auswegs aus der sich immer stärker abzeichnenden Sackgasse haben drei Themen abzustecken erlaubt, deren Betrachtung lohnt: (1) der Zustand der polnischen Religiosität, (2) die pastoralen Konsequenzen, die sich aus der von den Konzilsvätern erarbeiteten „Communio-Ekklesiologie” ergeben, und (3) die in die Sprache einer bestimmten Bewegung, einer bestimmten Aktivität „übersetzte” Ekklesiologie des Konzils in ihren zentralen Elementen: der Person, der Gemeinschaft des Volkes Gottes, der apostolischen Gemeinschaft. Jedes davon kann den Gegenstand einer gesonderten Studie oder mehrerer Bücher bilden. In dieser Arbeit skizzieren wir lediglich die Hauptlinien der Reflexion.

Schlüsselbegriffe: Charisma, (Deutero-)Katechumenat, Diakonie, CommunioEkklesiologie, Evangelisierung, Elitegruppen, Individualismus, Initiation, Pfarrei, Pluralismus, Religiosität, Bewegung „Licht-Leben”, Pastoraltheologie, Gemeinschaft.

\section{MEET THE CHALLENGE FOR THE EVANGELIZATION. THE TO- PICALITY OF RECOMMENDATIONS MADE BY REV. FRANCISZEK BLACHNICKI}

\section{Summary}

The initial reflection on the state of the Polish pastoral work, the contemporary religiousness of Polish people and the possibility of leaving the increasing deadlock behind allowed for circling three subjects which are worth consideration: (1) the state of the Polish religiousness, (2) the pastoral consequences resulting from » ecclesiology communio « developed by the Fathers of the Vatican Council, (3) and, " translated « into a language of some movement, some action, the ecclesiology of the Vatican Council in her central elements: a person, the community of God's people, the apostolic community. Each of them can constitute the subject of the separate study or several books. In this study, we will circle only the lines of reflection.

Keywords: charisma, (deutero) catechumen, social work, » ecclesiology communio ", evangelization, elite groups, individualism, initiation, parish, pluralism, religiousness, Light-Life Movement, pastoral theology, community. 